This is an Accepted Manuscript of an article published by Elsevier in Environmental Research on 9 Jul 2018, available online:

https://doi.org/10.1016/i.envres.2018.07.018.

(C) 2018. This manuscript version is made available under the CC-BY-NC-ND 4.0 license http://creativecommons.org/licenses/by-nc-nd/4.0/ 


\title{
How to tackle the stringent sulfate removal requirements in mine water treatment $-A$ review of potential methods
}

\author{
Hanna Runtti ${ }^{1}$, Emma-Tuulia Tolonen ${ }^{1}$, Sari Tuomikoski ${ }^{1}$, Tero Luukkonen ${ }^{2}$, Ulla Lassi ${ }^{1,3}$
}

1. University of Oulu, Research Unit of Sustainable Chemistry, P.O Box 4300, FI-90014, University of Oulu, Finland

2. University of Oulu, Fibre and Particle Engineering Research Unit, P.O. Box 4300, FI-90014, University of Oulu, Finland

3. University of Jyvaskyla, Kokkola University Consortium Chydenius, Unit of Applied Chemistry, Talonpojankatu 2B, FI-67100 Kokkola, Finland

Corresponding author: Tero Luukkonen, email: tero.luukkonen@oulu.fi

\begin{abstract}
Sulfate $\left(\mathrm{SO}_{4}{ }^{2-}\right)$ is a ubiquitous anion in natural waters. It is not considered toxic, but it may be detrimental to freshwater species at elevated concentrations. Mining activities are one significant pathway to the release of anthropogenic sulfate into natural waters, mainly due to the exposure of sulfide mineral ores to weathering. There are several strategies for mitigating sulfate release, starting from preventing sulfate formation in the first place and ending at several end-of-pipe treatment options. Currently, the most widely used sulfate-removal process is its precipitation as gypsum $\left(\mathrm{CaSO}_{4} \cdot 2 \mathrm{H}_{2} \mathrm{O}\right)$. However, the lowest reachable concentration is theoretically $1500 \mathrm{mg} \mathrm{L}^{-1}$ $\mathrm{SO}_{4}{ }^{2-}$ due to gypsum's solubility. At the same time, several mines worldwide have significantly more stringent sulfate discharge limits. The purpose of this review is to examine the process options to reach low sulfate levels $\left(<1500 \mathrm{mg} \mathrm{L}^{-1}\right)$ in mine effluents. Examples of such processes include alternative chemical precipitation options, membrane technology, biological treatment, ion exchange, and adsorption. In addition, aqueous chemistry and current effluent standards concerning sulfate together with concentrate treatment and sulfur recovery are discussed.
\end{abstract}

Keywords: acid mine drainage; discharge limits; sulfate; sulfur recovery; water contamination

\section{Introduction and background}

The main sources of sulfur to natural waters are solubilization from minerals, fertilizers, atmospheric precipitation, and dry deposition (Wetzel 2001). Mining activities are significant point-sources of anthropogenic aqueous sulfur as sulfate $\left(\mathrm{SO}_{4}{ }^{2-}\right)$ concentrations in mine waters can explicitly exceed $10000 \mathrm{mg} \mathrm{L}^{-1}$ (de la Torre et al., 2011). However, sulfate is a naturally occurring ubiquitous major anion: its concentration varies typically from $0-630 \mathrm{mg} \mathrm{L}^{-1}$ in rivers, $2-250 \mathrm{mg} \mathrm{L}^{-1}$ in lakes, and 0$230 \mathrm{mg} \mathrm{L}^{-1}$ in ground water (UNEP 1990). The typical level of sulfate in seawater is approximately $2700 \mathrm{mg} \mathrm{L}^{-1}$ (Hitchcock 1975). In rainwater, sulfate concentration is approximately 1-6 $\mathrm{mg} \mathrm{L}^{-1}$ (Franklin et al., 1985; WHO/UNEP 1989), but it has been declining as a result of atmospheric sulfur emission reduction policies (Vet et al., 2014).

Sulfate is not considered toxic as such, but it can cause diarrhea, dehydration, catharsis, and changes in methaemoglobin and sulfhaemoglobin levels in humans and animals when ingested in large amounts (Cocchetto and Levy 1981; Digesti and Weeth 1976; Gomez et al., 1995; Paterson et al., 1979). In freshwater species, sulfate can be directly lethal at elevated concentrations due to 
osmoregulatory stress (Soucek and Kennedy 2005). However, as an example, sulfate has been found to be less toxic to freshwater daphnids than other major ions such as $\mathrm{K}^{+}, \mathrm{Mg}^{2+}, \mathrm{HCO}_{3}{ }^{-}$, or $\mathrm{Cl}^{-}\left(\mathrm{Mount}^{2}\right.$ et al., 1997). Nevertheless, sulfate is a contributor to the salinization of freshwater bodies and is therefore seen as an urgent environmental issue (Cañedo-Argüelles et al., 2013). In addition to the environmental and health effects, sulfate causes the deterioration of concrete (i.e., sulfate attack) (Glasser et al., 2008; Monteiro 2005) and increases the corrosion rate of concrete reinforcements (Al-Tayyib and Shamim Khan 1991; Dehwah et al, 2002). Sulfate also enhances metal release from corrosion scales in water pipes (Sun et al., 2017). However, sulfate also acts as a pitting corrosion inhibitor by providing a supporting electrolyte that reduces the migration of, for instance, chloride into pits (Frankel 1998). Under anaerobic conditions, sulfate can be bacterially reduced to hydrogen sulfide $\left(\mathrm{H}_{2} \mathrm{~S}\right)$, which is significantly more toxic (Doujaiji and Al-Tawfiq 2010; Reiffenstein et al., 1992) and causes microbiologically influenced corrosion (Enning and Garrelfs 2014).

The speciation of sulfur is presented in Fig. 1. Sulfate is present as either deprotonated $\mathrm{SO}_{4}{ }^{2-}(\mathrm{pH}>$ approx. 2) or in the protonated form, $\mathrm{HSO}_{4}{ }^{2-}(\mathrm{pH}<$ approx. 2). The reduction of sulfate to sulfide requires a very strong reducing agent, such as $\mathrm{Cr}$ (II) (Stone and Forstner 1957), and thus does not occur in natural aqueous environments by chemical means. However, sulfate can be reduced by hydrocarbons at elevated temperatures (approx. 100-180 ${ }^{\circ} \mathrm{C}$ ), which is referred to as thermochemical sulfate reduction and causes the high concentrations of hydrogen sulfide in oil reservoirs (Goldstein and Aizenshtat 1994; Machel 2001). However, in practice, the most common pathway to sulfate reduction is via the action of sulfate reducing bacteria (SRB), such as Desulfovibrio vulgaris.

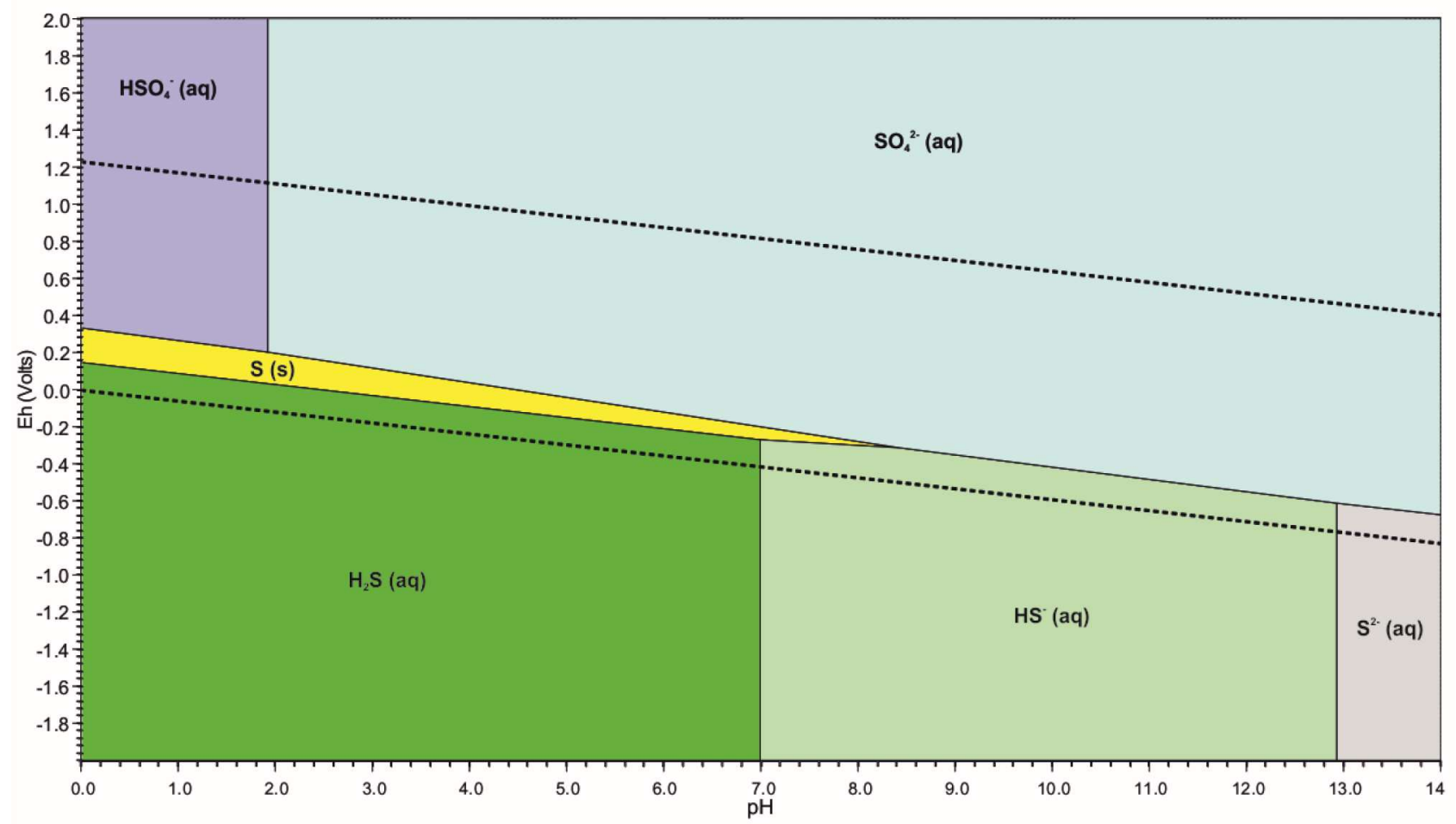

Figure 1. Eh-pH diagram of sulfur illustrated with the HSC Chemistry software.

Sulfate in mine water originates mainly from the geochemical weathering of rocks and to a lesser extent from sulfur-containing process chemicals. When elemental sulfur $\left(S^{0}\right)$ or sulfides (such as pyrite, $\mathrm{FeS}_{2}$ ) are oxidized in the presence of water, and frequently catalyzed by micro-organisms, 
sulfuric acid is generated according to the frequently used overall reactions 1 and 2 (Rayner-Canham 1999; Silva et al., 2012). The water stream in which reactions occur is referred to as acid mine drainage (AMD) (Heikkinen et al., 2009). AMD formation also continues after mine closure if appropriate management is not practiced (Ríos et al., 2008).

$\mathrm{FeS}_{2}(\mathrm{~s})+3 \frac{1}{2} \mathrm{O}_{2}(\mathrm{aq})+\mathrm{H}_{2} \mathrm{O} \rightarrow \mathrm{FeSO}_{4}(\mathrm{aq})+\mathrm{H}_{2} \mathrm{SO}_{4}(\mathrm{aq})$

$2 \mathrm{~S}(\mathrm{~s})+3 \mathrm{O}_{2}(\mathrm{aq})+\mathrm{H}_{2} \mathrm{O} \rightarrow 2 \mathrm{H}_{2} \mathrm{SO}_{4}(\mathrm{aq})$

It should be noted, though, that pyrite oxidation is a multistep process (Johnson and Hallberg 2005) and that the main oxidant is usually ferric iron ( $\mathrm{Fe}^{3+}$ ) instead of dissolved oxygen (Evangelou 1995). A more thorough set of reactions occurring during pyrite, arsenopyrite (FeAsS), or chalcopyrite (CUFeS) oxidation can be represented by reactions 3-7, 8-10, and 11-12, respectively (Parviainen 2012). The oxidation reactions can also result in the formation of metastable anions, such as sulfite $\left(\mathrm{SO}_{3}{ }^{-}\right)$, thiosulfate $\left(\mathrm{S}_{2} \mathrm{O}_{3}{ }^{2-}\right)$, and polythionates $\left(\mathrm{S}_{\mathrm{n}} \mathrm{O}_{6}{ }^{2-}\right)$, which will eventually be oxidized into sulfate (Descostes et al., 2004; Moses et al., 1987).

$$
\begin{aligned}
& \mathrm{FeS}_{2}(\mathrm{~s})+7 / 2 \mathrm{O}_{2}(\mathrm{aq})+\mathrm{H}_{2} \mathrm{O} \rightarrow \mathrm{Fe}^{2+}(\mathrm{aq})+2 \mathrm{SO}_{4}^{2-}(\mathrm{aq})+2 \mathrm{H}^{+}(\mathrm{aq}) \\
& \mathrm{Fe}^{2+}(\mathrm{aq})+1 / 4 \mathrm{O}_{2}(\mathrm{aq})+\mathrm{H}_{2} \mathrm{O} \rightarrow \mathrm{Fe}^{3+}(\mathrm{aq})+1 / 2 \mathrm{H}_{2} \mathrm{O} \\
& \mathrm{FeS}_{2}(\mathrm{~s})+14 \mathrm{Fe}^{3+}(\mathrm{aq})+8 \mathrm{H}_{2} \mathrm{O} \rightarrow 15 \mathrm{Fe}^{2+}(\mathrm{aq})+2 \mathrm{SO}_{4}{ }^{2-}(\mathrm{aq})+16 \mathrm{H}^{+}(\mathrm{aq}) \\
& \mathrm{FeS}_{2}(\mathrm{~s})+15 / 4 \mathrm{O}_{2}(\mathrm{aq})+7 / 2 \mathrm{H}_{2} \mathrm{O} \rightarrow \mathrm{Fe}(\mathrm{OH})_{3}(\mathrm{~s})+2 \mathrm{SO}_{4}{ }^{2-}(\mathrm{aq})+4 \mathrm{H}^{+}(\mathrm{aq}) \\
& \mathrm{Fe}_{(1-\mathrm{x})} \mathrm{S}(\mathrm{s})+(2-\mathrm{x} / 2) \mathrm{O}_{2}(\mathrm{aq})+\mathrm{xH}_{2} \mathrm{O} \rightarrow(1-\mathrm{x}) \mathrm{Fe}^{2+}(\mathrm{aq})+\mathrm{SO}_{4}^{2-}+2 \mathrm{xH}^{+}(\mathrm{aq}) \\
& \mathrm{FeAsS}_{(\mathrm{s})}+11 / 4 \mathrm{O}_{2}(\mathrm{aq})+3 / 2 \mathrm{H}_{2} \mathrm{O} \rightarrow \mathrm{Fe}^{2+}(\mathrm{aq})+\mathrm{H}_{3} \mathrm{AsO}_{3}(\mathrm{aq})+\mathrm{SO}_{4}{ }^{2-}(\mathrm{aq}) \\
& \mathrm{H}_{3} \mathrm{AsO}_{3}(\mathrm{aq})+1 / 2 \mathrm{O}_{2}(\mathrm{aq}) \rightarrow \mathrm{HAsO}_{4}^{2-}(\mathrm{aq})+2 \mathrm{H}^{+}(\mathrm{aq}) \\
& \mathrm{FeAsS}(\mathrm{s})+7 / 2 \mathrm{O}_{2}(\mathrm{aq})+6 \mathrm{H}_{2} \mathrm{O} \rightarrow \mathrm{Fe}(\mathrm{OH})_{3}(\mathrm{~s})+\mathrm{SO}_{4}^{2-}(\mathrm{aq})+\mathrm{H}_{2} \mathrm{AsO}_{4}^{-}(\mathrm{aq})+3 \mathrm{H}^{+}(\mathrm{aq}) \\
& 2 \mathrm{CuFeS}_{2}(\mathrm{~s})+4 \mathrm{O}_{2}(\mathrm{aq}) \rightarrow 2 \mathrm{Cu}^{2+}(\mathrm{aq})+\mathrm{Fe}^{2+}(\mathrm{aq})+\mathrm{SO}_{4}^{2-}(\mathrm{aq}) \\
& 2 \mathrm{CuFeS}_{2}(\mathrm{~s})+17 / 2 \mathrm{O}_{2}(\mathrm{aq})+5 \mathrm{H}_{2} \mathrm{O} \rightarrow 2 \mathrm{Cu}^{2+}(\mathrm{aq})+2 \mathrm{Fe}(\mathrm{OH})_{3}(\mathrm{~s})+4 \mathrm{SO}_{4}{ }^{2-}(\mathrm{aq})+4 \mathrm{H}^{+}(\mathrm{aq})
\end{aligned}
$$

Only few natural processes, such as the naturally occurring precipitation of gypsum $\left(\mathrm{CaSO}_{4} \cdot 2 \mathrm{H}_{2} \mathrm{O}\right)$, epsomite $\left(\mathrm{MgSO}_{4} \cdot 7 \mathrm{H}_{2} \mathrm{O}\right)$, jarosite $\left((\mathrm{K}, \mathrm{Na}, \mathrm{H}) \mathrm{Fe}_{3}\left(\mathrm{SO}_{4}\right)_{2}(\mathrm{OH})_{6}\right)$, or other secondary minerals, remove sulfate from ground and surface waters (Lottermoser 2010). Therefore, sulfate has a relatively long residence time in the aqueous environment once it is released. The direct and indirect environmental concerns of sulfate release have led to continuously more stringent sulfate removal requirements for mines worldwide, which cannot be attained via the traditionally used gypsum precipitation. The theoretical minimum concentration with gypsum precipitation is $1500 \mathrm{mg} \mathrm{L}^{-1}$ $\mathrm{SO}_{4}{ }^{2-}$ (at $20^{\circ} \mathrm{C}$ ) due to the solubility of gypsum (Geldenhuys et al., 2003). Consequently, the aim of this review paper is to present an up-to-date overview of recent research results of the available sulfate removal methods with a special emphasis on the technologies and combinations of technologies capable of reducing sulfate to levels lower than with conventional gypsum precipitation. The possibility to recover sulfur chemicals from mine effluents is also briefly discussed.

\section{Sulfate guideline levels and discharge limits}

In drinking water, the recommended sulfate level is $250 \mathrm{mg} \mathrm{L}^{-1}$ (WHO 2017), but some countries have set stricter sulfate recommendations to prevent the corrosion of pipes (e.g., less than $150 \mathrm{mg}$ $\mathrm{L}^{-1}$ in Finland (Ministery of Social Affairs and Health, 461/2000)). The sulfate discharge limits for mine drainage and other industrial effluents vary typically from 250 to $1000 \mathrm{mg} \mathrm{L}^{-1}$ (Liang 2014; 
Namasivayam and Sureshkumar 2007; Silva et al., 2012). For example, in Chile, the sulfate limits for groundwater and surface water discharge are $250-500 \mathrm{mg} \mathrm{L}^{-1}$ and $1000-2000 \mathrm{mg} \mathrm{L}^{-1}$, respectively (Jarvie-Eggart 2015). There is considerable variation in sulfate discharge limits among countries and even among mines within a country depending on the characteristics of the receiving water body. In an extreme case, the sulfate limit can be as low as $10 \mathrm{mg} \mathrm{L}^{-1}$, as in the U.S. state of Minnesota to protect wild rice (Minnesota Pollution Control Agency 2014). In Finland, as another example, authorities have just in recent decades started to set limits for sulfate in mine water discharge: the limits range between $1000-4000 \mathrm{mg} \mathrm{L}^{-1}$, but there are still active sulfide ore mines without sulfate discharge limits.

Another means of measuring sulfate (and other dissolved ions) is as total dissolved solids (TDS, $\mathrm{mg}$ $\mathrm{L}^{-1}$ ) (INAP 2003). Theoretically, $1 \mathrm{mg} \mathrm{L}^{-1}$ of dissolved ions contributes $1 \mathrm{mg} \mathrm{L}^{-1}$ to the TDS value. In practice, TDS are measured based on electrical conductivity (Equation 13).

$T D S=E C \times f$,

where EC is electrical conductivity $\left(\mu \mathrm{S} \mathrm{cm}^{-1}\right)$, and $\mathrm{f}$ is the conversion factor (dimensionless). For 45 South African bodies of mine waters, the average $f$ was determined to be 0.85 , while 0.67 is frequently used as an approximation if the factor is not known (Hubert and Wolkersdorfer 2015). On the other hand, each $\mathrm{mg} \mathrm{L}^{-1}$ of sulfate contributes $1.54 \mu \mathrm{S} \mathrm{cm}^{-1}$ (at $25^{\circ} \mathrm{C}$ ) to conductivity (Clescerl et al. 1999).

\section{Sulfate removal technologies}

To preventing the formation of AMD and sulfate-containing process wastewaters should be the first means in preserving the environment from aqueous sulfate emissions. This can be done by the management of rock waste and tailings (Kefeni et al., 2017) and by optimizing the process conditions. Once AMD or sulfate-containing process wastewater is formed, it should be managed and treated properly (Kefeni et al., 2017). In recent years, not only sulfate removal but also the recovery and recycling of sulfate have become goals in the remediation of sulfate effluents. The recovery of the sulfur chemical can take place from concentrates or solids formed in various treatment processes.

There are several techniques available for sulfate removal from effluents, as discussed in the below sections. Mine effluent treatment options can be fundamentally divided into active and passive, of which the first refers to a process requiring pumping, mechanical devices, and a continuous supply of chemicals, electricity, and maintenance, whereas the latter utilizes gravitational water flow and natural chemical and biological processes (Lottermoser 2010).

\subsection{Precipitation}

In the gypsum precipitation of sulfate, an alkaline chemical, such as lime (Reaction 14), is used to raise the mine water $\mathrm{pH}$ typically to 9.5. Limestone (Reaction 15) can also be used, but it can only raise the mine water $\mathrm{pH}$ up to approximately 7 (Maree et al., 2004a).The use of industrial byproducts as alternative calcium sources have also been investigated (Alakangas et al., 2013; Mackie et al., 2010a; Mackie et al., 2010b; Mackie and Walsh 2012; Tolonen et al., 2014). Gypsum 
precipitation is a well-known method that has been used for decades due to its effectiveness for the treatment of highly acidic mine waters, the relative simplicity of the process, and its tolerance toward temperature fluctuations (Brown et al., 2002). However, the use of gypsum precipitation as the sole process is not frequently effective enough to meet environmental limits when easily soluble metal sulfates, such as sodium sulfate, are present in water (Geldenhuys et al., 2003). Other shortcomings of the process include the formation of large amounts of sludge with limited options for usage, high water content in the produced sludge, difficulties in the dewatering of the sludge, high sludge disposal costs, and the scaling of equipment and pipelines (Chen et al., 2009; Matlock et al., 2002). Polymers, such as polyacrylamides and polyamines, can be used to enhance dewatering and improve the floc strength of the gypsum precipitate. Part of the sludge can also be recycled within the gypsum precipitation process, which is called the high-density sludge (HDS) process (Aube and Lee 2015). In the HDS process, the precipitates are formed onto recycled particles, creating larger and denser precipitates that can be more easily settled and dewatered (Aube and Lee 2015). Gypsum solubility limits the minimum reachable sulfate concentration to $1500 \mathrm{mg} \mathrm{L}^{-1}$ (at $20{ }^{\circ} \mathrm{C}$ ) when no sodium or magnesium ions are present (Geldenhuys et al., 2003). However, with the high $\mathrm{pH}$ lime treatment $(\mathrm{pH}>11)$, magnesium no longer inhibits sulfate removal as it precipitates as hydroxide, enhancing the gypsum precipitation (Tolonen et al., 2015).

$$
\begin{aligned}
& \mathrm{Ca}(\mathrm{OH})_{2}(\mathrm{~s})+\mathrm{H}_{2} \mathrm{SO}_{4} \rightarrow \mathrm{CaSO}_{4} \cdot 2 \mathrm{H}_{2} \mathrm{O}(\mathrm{s}) \\
& \mathrm{Ca}\left(\mathrm{CO}_{3}\right)(\mathrm{s})+\mathrm{H}_{2} \mathrm{SO}_{4}+\mathrm{H}_{2} \mathrm{O} \rightarrow \mathrm{CaSO}_{4} \cdot 2 \mathrm{H}_{2} \mathrm{O}(\mathrm{s})+\mathrm{CO}_{2}(\mathrm{~g})
\end{aligned}
$$

Ettringite $\left(\mathrm{Ca}_{6} \mathrm{Al}_{2}\left(\mathrm{SO}_{4}\right)_{3}(\mathrm{OH})_{12} \cdot 26 \mathrm{H}_{2} \mathrm{O}\right)$ precipitation has been shown to be capable of reducing sulfate concentration down to $200 \mathrm{mg} \mathrm{L}^{-1}$ (Madzivire et al., 2010; Tolonen et al., 2016a; Tolonen et al., 2016b). However, the presence of magnesium in the treated water has been found to inhibit sulfate removal with ettringite precipitation (Dou et al., 2017). In ettringite precipitation, the $\mathrm{pH}$ of the effluent is increased to approximately 12 with lime, and aluminum salt is added, leading to the precipitation of ettringite (Reaction 16). The most commonly used aluminum salts are sodium aluminate and aluminum hydroxide, but the use of industrial aluminum-containing wastewaters has also been studied (Alvarez-Ayuso and Nugteren 2005). Electrocoagulation can also be used to provide aluminum ions to the ettringite precipitation process (Van der Meer et al., 2014). Similarly, as with gypsum precipitation, polymers can be used to aid precipitate quality. When ettringite precipitation is used for waters with a high sulfate concentration ( $>3000 \mathrm{mg} \mathrm{L}^{-1}$ ), it may be economical to use the conventional lime precipitation as a pre-treatment. This decreases the consumption of the more expensive aluminum chemicals. The $\mathrm{pH}$ after ettringite precipitation can be decreased to meet the discharge limits by treating it with $\mathrm{CO}_{2}$, which results in the precipitation of calcite $\left(\mathrm{CaCO}_{3}\right)$. The operational costs of ettringite precipitation can be lowered by regenerating the aluminum salt by decomposing the precipitated ettringite (Smit 1999) or by further using the precipitated ettringite, for example, as a sorbent for arsenate removal (Tolonen et al., 2016a; Tolonen et al., 2016b). HDS process can be used to obtain denser sludge (Sapsford and Tufvesson 2017).

$6 \mathrm{Ca}(\mathrm{OH})_{2}+3 \mathrm{H}_{2} \mathrm{SO}_{4}+2 \mathrm{Al}(\mathrm{OH})_{3}(\mathrm{~s})+2 \mathrm{OH}_{2} \mathrm{O} \rightarrow \mathrm{Ca}_{6} \mathrm{Al}_{2}\left(\mathrm{SO}_{4}\right)_{3}(\mathrm{OH})_{12} \cdot 26 \mathrm{H}_{2} \mathrm{O}(\mathrm{s})$

Chemical jarosite $\left(\mathrm{XFe}_{3}\left(\mathrm{SO}_{4}\right)_{2}(\mathrm{OH})_{6}\right.$, where $\mathrm{X}$ is usually a mixture of $\mathrm{Na}^{+}$and $\mathrm{K}^{+}$) precipitation (Reaction 17) is a process used in hydrometallurgical processes for dissolved iron removal from acid leach solutions before, for instance, zinc recovery (Dutrizac 1999). Jarosite is also a commonly encountered natural secondary mineral precipitate in AMD (Valentene and Gomes 2009). Chemical 
jarosite precipitation requires low $\mathrm{pH}(0-4)$, high temperature $\left(130-140^{\circ} \mathrm{C}\right)$, high pressure $(5-7$ bar), and a reaction time of 1-3 hours (Nilsson and Jokinen 1997). Although chemical jarosite precipitation could theoretically be applied for mine effluents and other wastewaters (Shengfeng et al., 2007) the reported results have been poor, and the required harsh reaction conditions further decrease its feasibility (Tait et al., 2009). Also, the management of jarosite precipitates would introduce problems as decreased acidity promotes the dissolution of jarosite. Consequently, chemical jarosite precipitation is likely not a practical method for sulfate removal from mine effluents. However, biological or combined chemical and biological jarosite precipitation could have potential for sulphate removal from AMD(Nurmi et al., 2010).

$3 \mathrm{Fe}_{2}\left(\mathrm{SO}_{4}\right)_{3}+\mathrm{Na}_{2} \mathrm{SO}_{4}+12 \mathrm{H}_{2} \mathrm{O} \rightarrow 2 \mathrm{NaFe}_{3}\left(\mathrm{SO}_{4}\right)_{2}(\mathrm{OH})_{6}(\mathrm{~s})+6 \mathrm{H}_{2} \mathrm{SO}_{4}$

The precipitation of sulfate via barite can be implemented with barium salts, such as barium hydroxide, sulfide, or carbonate (Reactions 18-20, respectively) (Bologo et al., 2012; Bosman et al., 1990; Hlabela et al., 2007; INAP 2003; Kefeni et al., 2015; ). Barium hydroxide and sulfide can be used to treat highly acidic mine waters directly, but in the case of barium carbonate, pre-treatment with, for example, lime is needed (Adlem et al., 1991). When using barium sulfide, hydrogen sulfide stripping is needed (Kefeni et al, 2015; Maree et al., 2004b). Sulfate removal from mine water with barite precipitation has been reported to result in sulfate concentration below $200 \mathrm{mg} \mathrm{L}^{-1}$ (Adlem et al., 1991; Hlabela et al., 2007; Maree et al., 2004b). The solubility of barite is very low (Benatti et al. 2009). However, the barite precipitants are expensive and toxic. The process also generates bariumcontaining waste that needs to be disposed (Benatti et al., 2009) or, preferably, recycled. For instance, $\mathrm{BaSO}_{4}$ can be thermally reduced to $\mathrm{BaS}$ and further converted to $\mathrm{BaCO}_{3}$ and $\mathrm{H}_{2} \mathrm{~S}$ by passing $\mathrm{CO}_{2}$ through $\mathrm{BaS}$ solution (Hlabela et al., 2007). $\mathrm{BaCO}_{3}$ can be thermally decomposed to $\mathrm{BaO}$ and further hydrolyzed to $\mathrm{Ba}(\mathrm{OH})_{2}$ (Adlem et al., 1991). Also, the produced effluent requires the monitoring of barium traces and possibly post-treatment (Benatti et al., 2009).

$$
\begin{aligned}
& \mathrm{Ba}(\mathrm{OH})_{2}(\mathrm{~s})+\mathrm{H}_{2} \mathrm{SO}_{4} \rightleftharpoons \mathrm{BaSO}_{4}(\mathrm{~s})+2 \mathrm{H}_{2} \mathrm{O} \\
& \mathrm{BaS}(\mathrm{s})+\mathrm{H}_{2} \mathrm{SO}_{4} \rightleftharpoons \mathrm{BaSO}_{4}(\mathrm{~s})+\mathrm{H}_{2} \mathrm{~S}(\mathrm{~g}) \\
& \mathrm{BaCO}_{3}(\mathrm{~s})+\mathrm{H}_{2} \mathrm{SO}_{4} \rightleftharpoons \mathrm{BaSO}_{4}(\mathrm{~s})+\mathrm{H}_{2} \mathrm{CO}_{3}
\end{aligned}
$$

In addition, iron anodes have been reported to work successfully in sulfate removal from synthetic effluent by electrocoagulation although the exact removal mechanism remained unexplained: the formation of species such as $\mathrm{Fe}_{2}\left(\mathrm{SO}_{4}\right)_{3}$ among other coagulation mechanisms was speculated (Mamelkina et al. 2017). Sulfate removal from beamhouse and tannery wastewater and also synthetic samples by adsorption on metal oxides/hydroxides formed in electrocoagulation treatment has also been speculated (Murugananthan et al. 2004). When comparing iron and aluminum anodes, the latter was found to result in a better removal of sulfate (Nariyan et al., 2017). One additional possible removal mechanism is the adsorption of sulfate on the formed aluminum flocs (Sandoval et al., 2017).

\subsection{Adsorption}

Sulfate removal with adsorption has been studied with a wide range of materials: activated carbon (Hong et al., 2014; Hong et al., 2017; Hou et al., 2014; Salman 2009), fly ash (Koshy and Singh 2016), modified geopolymers (Runtti et al., 2016a), modified zeolites (Oliveira and Rubio 2007a; Runtti et al., 2017; Vujaković et al., 2000), and limestone (lakovleva et al., 2015; Silva et al., 2012), modified 
coir pith (Namasivayam and Sureshkumar 2007), modified rice straw (Cao et al., 2011), nanoalumina (Katal et al., 2012), soils (Bazer-Bachi et al., 2007; Delfosse et al., 2006; Gustafsson et al., 2015), iron sand, and pulp and paper waste (lakovleva et al., 2015). Chemical modification has been performed, for instance, with polypyrrole (Hong et al., 2014; Hong et al., 2017; Hou et al., 2014), $\mathrm{BaCl}_{2}$ (Runtti et al., 2016a; Runtti et al., 2017), $\mathrm{ZnCl}_{2}$, (Namasivayam and Sangeetha 2008), $\mathrm{NaOH}$ (Moret and Rubio 2003), $\left(\mathrm{NH}_{4}\right)_{2} \mathrm{~S}_{2} \mathrm{O}_{8}$ (Sang et al., 2013) and $\mathrm{ZrOCl}_{2} \cdot 8 \mathrm{H}_{2} \mathrm{O}$ (Mulinari and da Silva 2008), and cationic surfactants (Rui et al., 2011). The modification has frequently aimed to convert surface surface charge into positive or introduce sulfate-precipitating elements (such as $\mathrm{Ba}$ ) in the adsorbent structure.

Adsorption mechanisms of sulfate has been in dispute, but the suggested mechanism is the formation of an oxi-hydroxide layer on the surface and a change of the surface charge into positive (i.e., Coulumb interaction between surface and sulfate anion) as summarized by Runtti et al. (2016a) and the references therein. Furthermore, the ligand exchange with the formation of surface outerand inner-sphere complexes have role in the mechanism (Rahnemaie et al., 2006). In addition, surface precipitation onto the adsorbent contributes to the removal on some cases (Ishiguro et al., 2006; Sokolova and Alekseeva 2008).

Adsorption, in general, has potential to be an effective and economic method (Fu and Wang 2011; Gupta et al., 2013; Yavuz et al., 2003). However, there are many factors in industrial applications that affect the technical and economic feasibility. First, the adsorbent should have high adsorption capacity and selectivity for sulfate. Currently, there is a lack of commercially available adsorbents specifically for sulfate removal from mine effluents. However, a recent patent application describes an adsorbent for the removal of sulfur substances (Aalto et al., 2017). The raw materials and the preparation of the adsorbent (including possible chemical modification) should be as inexpensive, simple, and environmentally friendly as possible. Finally, the adsorbent should be regenerable, otherwise the operational costs arising from the continuous consumption of the adsorbent will likely be too high for large-scale use. In industrial applications, adsorption is generally performed with continuous flow reactors. The treatment efficiency is determined by $\mathrm{pH}$, temperature, concentration, flow rate, mass of sorbent (bed volume), and ionic strength, for instance. Most likely the most economical use for adsorption would be after other sulfate removal methods in cases where extremely low sulfate concentrations are required. The existing literature on sulfate adsorbents is summarized in Table 1. 
Table 1. Different adsorbents for sulfate removal.

\begin{tabular}{|c|c|c|c|c|c|c|c|c|}
\hline Adsorbent & Effluent type & $\begin{array}{l}\text { Adsorption } \\
\text { capacity } \\
\text { qe [mg/g] }\end{array}$ & $\begin{array}{l}\text { Initial } \\
\mathrm{pH}\end{array}$ & $\begin{array}{l}\mathrm{C}_{0} \\
{[\mathrm{mg} / \mathrm{L}]}\end{array}$ & $\begin{array}{l}\text { Sorbent } \\
\text { dose } \\
{[\mathrm{g} / \mathrm{L}]}\end{array}$ & $\begin{array}{l}\text { Contact } \\
\text { time } \\
\text { [h] }\end{array}$ & $\begin{array}{l}\mathrm{T} \\
{\left[{ }^{\circ} \mathrm{C}\right]}\end{array}$ & Reference \\
\hline $\begin{array}{l}\text { Chitosan-graft- } \\
\text { Polyacrylamide } \\
\text { copolymer }\end{array}$ & Synthetic & $277.78^{1}$ & $<4$ & $500-3000$ & 3 & - & - & Fosso-Kankeu et al., 2015 \\
\hline $\begin{array}{l}\text { Chitin-based shrimp } \\
\text { shells }\end{array}$ & Synthetic & $156.0^{1}$ & 4.3 & $0-2350$ & 10 & 1 & 25 & Moret and Rubio 2003 \\
\hline Desilicated fly ash & AMD & $147.06^{2}$ & $10-12$ & - & 20 & 1 & 35 & Ntuli et al., 2016 \\
\hline $\begin{array}{lr}\text { Barium-modified } & \text { blast- } \\
\text { furnace } & \text { slag } \\
\text { geopolymer } & \text { (Ba-BFS- } \\
\text { GP) } & \end{array}$ & AMD & $119.0^{3}$ & $7-8$ & 865 & $1.3-15$ & 24 & $22-23$ & Runtti et al., 2016a \\
\hline $\begin{array}{l}\text { poly }(m- \\
\text { phenylenediamine })\end{array}$ & Synthetic & $108.5^{1}$ & $<3$ & $500-4000$ & 13.3 & 1 & 30 & Sang et al., 2013 \\
\hline $\begin{array}{l}\text { Barium-modified blast- } \\
\text { furnace } \\
\text { geopolymer } \\
\text { GP) }\end{array}$ & Synthetic & $91.1^{3}$ & $7-8$ & $100-1800$ & 5 & 24 & $22-23$ & Runtti et al., 2016a \\
\hline $\begin{array}{l}\text { Epichlorohydrin and } \\
\text { trimethylamine } \\
\text { modified rice straw }\end{array}$ & Synthetic & $74.76^{1}$ & 6.4 & $50-500$ & 2 & 2 & 25 & Cao et al., 2011 \\
\hline Ba-modified zeolite & Synthetic & $\begin{array}{l}64.10^{1} \\
\left(1.33 \mathrm{meq} \mathrm{g}^{-1}\right)\end{array}$ & 6.0 & $<1000$ & 10 & 2 & 25 & Oliveira et al. 2007 \\
\hline $\begin{array}{l}\text { Polypyrrole-grafted } \\
\text { granular activated } \\
\text { carbon }\end{array}$ & Synthetic & $48.0^{3}$ & - & $10-400$ & 2.5 & 24 & 20 & Hong et al. 2014 \\
\hline $\begin{array}{l}\text { Polypyrrole modified } \\
\text { hardwood-based } \\
\text { activated carbon }\end{array}$ & Synthetic & $44.7^{3}$ & $7-7.2$ & 250 & 2.5 & 24 & 20 & Hong et al. 2017 \\
\hline Alkali-treated fly ash & Groundwater & $43.0^{3}$ & 7 & 200 & $0-2$ & 2.5 & - & Geethamani et al. 2014 \\
\hline Metasomatite & Synthetic & $31.1^{4}$ & 2 & 1770 & 4 & 0.18 & - & Sadeghalvad et al., 2016 \\
\hline Andisols & Synthetic & $\begin{array}{l}28.2^{1} \\
(300 \mathrm{mmol} / \mathrm{kg})\end{array}$ & 4-7 & $\begin{array}{l}0.14-81660 \\
(0.0015- \\
850 \\
\mathrm{mmol} / \mathrm{L})\end{array}$ & 8.3 & 3 & - & Ishiguro et al., 2006 \\
\hline Quartz-albitophire & Synthetic & $26.2^{4}$ & 2 & 1950 & 4 & 2.17 & - & Sadeghalvad et al., 2016 \\
\hline Filter sand & Synthetic & $\begin{array}{l}25.07^{3} \\
\left(261 \mathrm{mmol} \mathrm{g}^{-1}\right)\end{array}$ & - & $20-2000$ & 40 & 480 & 22 & lakovleva et al. 2015 \\
\hline Limestone & Synthetic & $23.7^{1}$ & 6.5 & $50-3000$ & 25 & 9 & 23 & Silva et al. 2012 \\
\hline Flotation fines & Synthetic & $\begin{array}{l}21.23^{3} \\
\left(221 \mathrm{mmol} \mathrm{g}^{-1}\right)\end{array}$ & - & $20-2000$ & 40 & 480 & 22 & lakovleva et al. 2015 \\
\hline $\begin{array}{l}\mathrm{FeCl}_{3} \text { modified carbon } \\
\text { residue (MCR) }\end{array}$ & Synthetic & $19.6^{3}$ & 4 & $50-1000$ & 5 & 24 & $20-23$ & Runtti et al., 2016b \\
\hline $\begin{array}{l}\text { Electrochemically } \\
\text { polymerized.activated } \\
\text { carbon }\end{array}$ & Synthetic & $18.0^{3}$ & $7-7.2$ & 250 & 2.5 & 24 & 20 & Hou et al., 2014 \\
\hline $\begin{array}{l}\text { Barium-modified acid } \\
\text { washed analcime (Ba- } \\
\text { Ac-ANA) }\end{array}$ & Synthetic & $13.7^{3}$ & $3-6$ & $10-500$ & 5 & 3 & 23 & Runtti et al., 2017 \\
\hline Raw rice straw & Synthetic & $11.68^{1}$ & 6.4 & $50-500$ & 2 & 2 & 25 & Cao et al. 2011 \\
\hline Nano alumina & Synthetic & $10.86^{2}$ & 5.0 & 50 & $0.5-40$ & 0.6 & 20 & Katal et al. $2012 b$ \\
\hline $\begin{array}{l}\text { Surfactant modified } \\
\text { coir pith }\end{array}$ & Synthetic & $8.76^{1}$ & 2 & $10-50$ & 4 & - & 32 & Namasivayam \& Sureshkumar 2007 \\
\hline $\begin{array}{l}\text { Pristine hardwood- } \\
\text { based activated carbon }\end{array}$ & Synthetic & $4.0^{3}$ & $7-7.2$ & 250 & 2.5 & 24 & 20 & Hong et al. 2017 \\
\hline$\gamma-\mathrm{Al}_{2} \mathrm{O}_{3}$ & Synthetic & $7.7^{1}$ & 5.7 & $20-40$ & - & 24 & 25 & Wu et al. 2002 \\
\hline Activated carbon & Synthetic & $7.6^{3}$ & 2 & $50-1000$ & 5 & 24 & $20-23$ & Runtti et al., 2016b \\
\hline $\begin{array}{l}\text { Surfactant-modified } \\
\text { clinoptilolite }\end{array}$ & Synthetic & $\begin{array}{l}\sim 7.5^{1} \\
(\sim 78 \mathrm{mmol} / \mathrm{kg})\end{array}$ & 4.0-5.1 & $\begin{array}{l}96-500 \\
\mathrm{mg} / \mathrm{l} \\
(1-5.2 \\
\mathrm{mmol} / \mathrm{l})\end{array}$ & $5 \%(w / w)$ & 24 & 25 & Vujaković et al., 2000 \\
\hline $\begin{array}{l}\mathrm{ZnCl} 2 \text { activated coir pith } \\
\text { carbon }\end{array}$ & Synthetic & $4.9^{1}$ & 4.0 & $20-80$ & 10 & 0.75 & 35 & Namasivayam and Sangeetha 2008 \\
\hline $\begin{array}{l}\text { Barium-modified } \\
\text { zeolite (ZSM5-Na-Ba) }\end{array}$ & Synthetic & $3.8^{3}$ & $4-7$ & $10-1000$ & 5 & 3 & 23 & Runtti et al., 2017 \\
\hline $\begin{array}{l}\text { Surfactant-modified } \\
\text { palygorskite }\end{array}$ & Synthetic & $3.24^{1}$ & 4 & $20-130$ & 10 & 4 & 35 & Rui et al., 2011 \\
\hline Raw date palm seeds & Synthetic & $3.2^{3}$ & 3.5 & 100 & 10 & - & 25 & Koumaiti et al., 2011 \\
\hline $\begin{array}{l}\text { Barium-modified } \\
\text { analcime (Ba-ANA) }\end{array}$ & Synthetic & $2.3^{3}$ & $6-7$ & $10-1000$ & 5 & 3 & 23 & Runtti et al., 2017 \\
\hline Pulp and paper waste & Synthetic & $\begin{array}{l}2.786^{3} \\
\left(29 \mathrm{mmol} \mathrm{g}^{-1}\right)\end{array}$ & - & 20-2000 & 40 & 480 & 22 & lakovleva et al., 2015 \\
\hline $\begin{array}{l}\text { Soils of Sao Paulo } \\
\text { State, Brazil }\end{array}$ & Synthetic & $0.18-1.420^{3}$ & - & $0-0.156$ & 100 & 24 & - & Alves and Lavorenti 2004 \\
\hline Kaolinite & Synthetic & $1.2^{3}$ & 6 & - & 100 & 24 & 30 & Rao and Sridharan 1984 \\
\hline Iron sand & Synthetic & $\begin{array}{l}1.153^{3} \\
(12 \mathrm{mmolg}-1)\end{array}$ & - & $20-2000$ & 40 & 480 & 22 & lakovleva et al., 2015 \\
\hline Feldspar & Synthetic & $0.275^{1}$ & 5.5 & $1-5$ & 100 & 3 & 25 & Priyantha \& Parera 2000 \\
\hline Coir pith carbon & Synthetic & $0.06^{1}$ & 4.0 & $20-80$ & 10 & 0.75 & 35 & Namasivayam and Sangeetha 2008 \\
\hline
\end{tabular}

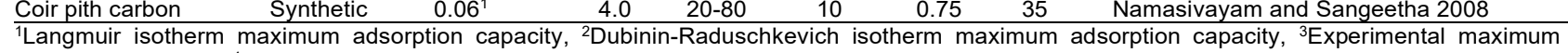
adsorption capacity, ${ }^{4} \mathrm{ANOVA}$. 


\section{3 lon exchange}

Ion exchange is the displacement of counter ions on the exchanger surface by impurity ions from the solution (Haghsheno et al., 2009; Sincero and Sincero 2003). Selective ion exchange media are available, and sulfate ions can typically be removed by weak base anion resins (Guimarães and Leão 2014; Sincero and Sincero 2003). Basic ion exchange resins consist of polymers (such as poly(styrene-divinylbenzene)) to which positively charged functional groups (such as tertiary amine) are attached, which act as exchange sites (Sincero and Sincero 2003). The number of these groups determines the exchange capacity, and the type of the groups determines the ion selectivity (Sincero and Sincero 2003). The affinity of most common anions for the ion exchange resin follows the sequence citrate $>\mathrm{SO}_{4}{ }^{2-}>\mathrm{NO}_{3}{ }^{-}>\mathrm{I}^{-}>\mathrm{Br}^{-}>\mathrm{Cl}^{-}>$formate $>$acetate $>\mathrm{F}^{-}$(Sincero and Sincero 2003). The patented GYP-CIX process consists of weak base anion and strong acid cation resins and is suitable for the effective removal of sulfate at concentration levels near the saturation stage of gypsum (INAP 2003). The GYP-CIX process was tested, for example, by Robertson et al. (1993) who found that the initial sulfate concentration ( $8000 \mathrm{mg} \mathrm{L}^{-1}$ ) was decreased to $1980 \mathrm{mg} \mathrm{L}^{-1}$ after gypsum precipitation and further to $200 \mathrm{mg} \mathrm{L}^{-1}$ by using the GYP-CIX process. Another process, called SulfIX, has been developed based on the GYP-CIX process (Doughty and Littlejohn 2015).

After the ion exchanger is saturated, it can be regenerated with, for instance, $\mathrm{NaOH}$ (suitable for strong base and weak base anion resins) (Valverde et al., 2006). In the GYP-CIX process, 2\% lime and $10 \%$ sulfuric acid solutions are used for the regeneration of the weak base anion and the strong acid cation resins, respectively. Furthermore, in the GYP-CIX process, the regeneration solutions are seeded with gypsum crystals, which promotes the precipitation of calcium as calcium sulfate (Schoeman and Steyn 2001). However, due to limited capacities and selectivities, ion exchange may not be suitable as primary technique, but rather after chemical precipitation (Feng et al., 2000).

\subsection{Biological treatment}

Microbial sulfate removal from AMD has been studied for over 50 years (Tuttle et al., 1969), and the number of publications on this topic is immense. The technology and related science has also been reviewed numerous times (Barton and Fauque 2009; Hansen 1994; Johnson and Hallberg 2005; Klein et al., 2014; Lens et al., 2002; Sánchez-Andrea et al., 2014; Sheoran et al., 2010; Wu et al., 2013). Therefore, the aim of this section is to provide a brief overview of the technical principles and focus summarizing recent publications.

Microbial sulfate removal from wastewater is based on the activity of sulfate reducing bacteria (SRB) and other prokaryotes capable of reducing sulfate (i.e., using it as a terminal electron acceptor) while oxidizing organic compounds or hydrogen (i.e., using them as electron donors) (Barton and Hamilton 2007). The formed sulfide can precipitate with metals or volatilize as hydrogen sulfide gas (Isosaari and Sillanpää 2017). Sulfate reduction by SRB typically takes place in anaerobic conditions (no free dissolved oxygen present) with a $\mathrm{pH}$ of 5-8 and an oxidation-reduction potential less than $-100 \mathrm{mV}$ (Postgate 1984). However, acidophilic and acid-tolerant SRB can survive at a lower pH; for instance, a pH of 4.0 was found to be optimum in one study (Santos and Johnson 2017). A high sulfate concentration $(3,500 \mathrm{mg} / \mathrm{L}$ ) was found to be initially inhibiting (i.e., the reactor became fully operational more slowly) for sulfate conversion in comparison to a lower concentration $(1,000$ $\mathrm{mg} / \mathrm{L}$ ) (Bernardez et al., 2012). SRB can tolerate cold temperatures, as documented for instance by Baldwin et al. (2016): a full-scale bioreactor had successfully operated for approximately 10 years 
at a temperature of $0-17{ }^{\circ} \mathrm{C}$ in Canada. In addition, several other studies (Auvinen et al., 2009; Sahinkaya et al., 2015; Tsukamoto et al., 2004) have indicated that microbial sulfate removal has potential for low temperature conditions but with a relatively lower sulfate reduction rate. Finally, it should be noted that SRB can use many other electron acceptors in addition to sulfate (e.g., nitrate is preferable), and they have to compete with other anaerobes for the available substrates (Muyzer and Stams 2008). The coexistence of different microbes can be, however, beneficial since SRB are unable to utilize complex organic compounds without fermentation (Muyzer and Stams 2008).

The generalized overall reaction occurring during microbial sulfate removal can be presented as follows (Reaction 21):

$8 \mathrm{H}^{+}(\mathrm{aq})+8 \mathrm{e}^{-}(\mathrm{aq})+\mathrm{SO}_{4}^{2-}(\mathrm{aq}) \rightarrow \mathrm{S}^{2-}(\mathrm{aq})+4 \mathrm{H}_{2} \mathrm{O}(\mathrm{aq})$

In the above reaction, the electrons can be supplied from hydrogen gas, acetate, propionate, butyrate, or lactate, for instance, as presented by reactions 22-26, respectively (Muyzer and Stams 2008):

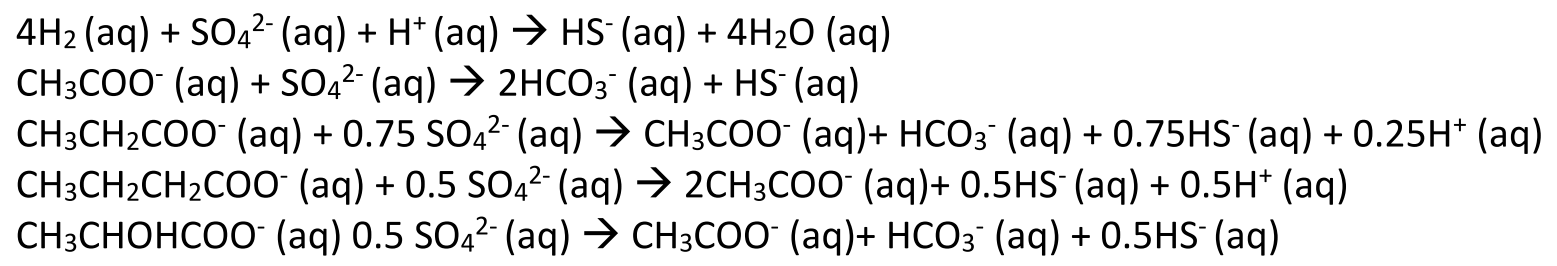

As with other AMD treatment processes, those involving SRB can be classified as passive or active. Active systems require the continuous management of chemicals and/or energy, while passive systems can operate several years without maintenance (Gusek and Schueck 2004; Rose et al., 2004; Rose et al., 2007). According to Skousen et al. (2017), passive biological systems capable of sulfate reduction are anaerobic constructed wetlands, vertical flow wetlands, and bioreactors. Similar systems are also sometimes called infiltration beds, alkalinity-producing systems, or successive alkalinity-producing systems (Isosaari and Sillanpää 2017; Skousen et al., 2017). When treating effluent from a closed mine, perhaps the simplest passive system is to add a suitable substrate directly to the flooded shafts (Bomberg et al., 2015). Active systems involving SRB, on the other hand, are referred to as sulfidogenic bioreactors.

Anaerobic constructed wetlands consist of vegetation on a permeable substrate (e.g., soil mixes, peat moss, spent mushroom compost, sawdust, manure) frequently mixed with limestone (Skousen et al., 2017). The substrate and vegetation act as electron donors and carbon and nutrient sources. The effluent flow direction is horizontal, and it typically occurs at the surface. The system generates alkalinity from sulfate reduction and from calcium carbonate dissolution. It is important to keep the conditions continuously anaerobic to prevent sulfate removal perturbations, ferric hydroxide formation, and subsequent clogging. Lefèvre et al. (2013) found that ethanol injection was an efficient means to recover an SRB process from oxygen exposure in comparison to several other methods. In vertical flow wetlands, effluent flows from an elevated (1-2 $\mathrm{m})$ pond through a substrate and limestone bed $(0.2-0.6 \mathrm{~m})$ in which oxygen is depleted and sulfate reduction occurs (Skousen et al., 2017). In terms of efficiency, an average $31 \%$ of $900 \mathrm{mg} / \mathrm{L}$ sulfate was removed during a two-year pilot using surface-flow wetland to treat AMD (O'Sullivan et al., 2004). Bioreactors (also known as compost bioreactors, sulfate-reducing bioreactors, or infiltration beds) are 
constructed of a covered bed of organic material and fine particle size limestone or other calcareous material through which AMD is allowed to flow vertically (Skousen et al., 2017). The design of passive systems for sulfate removal is discussed in numerous publications (Gusek 2004; Neculita and Zagury 2008; URS Corporation 2003). A typical feature of all such systems is a relatively long hydraulic retention time, as can be seen from Table 3. In addition, before the start-up of the treatment, the process needs a maturation period for suitable conditions and microbe strains to develop. The addition of bacteria inoculum (such as manure) can aid the start-up phase. Passive treatment systems perform relatively well for the first few months after start-up, but issues faced in the long-term performance include, leakage, a too-low $\mathrm{pH}$ level, seasonal variation, substrate limitations, and clogging problems (Neculita et al., 2007).

Sulfidogenic bioreactors are constructed and operated for the optimized production of hydrogen sulfide. They can be implemented in several set-ups, such as a continuously stirred tank reactor, an up-flow anaerobic sludge bed reactor, an expanded granular bed reactor, a fluidized bed reactor, a gas-lift bioreactor, or a membrane bioreactor (Bijmans 2008; Kousi et al., 2015). The advantage of active systems compared to passive ones is that they are more predictable and their performance is more controllable, which allows the selective recovery of metals in addition to effective sulfate removal. However, since the electron donors and other chemicals are continuously fed, the operational costs can be higher than with passive systems. Similar to passive systems, sulfidogenic bioreactors require a long hydraulic retention time (Table 3).

One of the most important aspects in the microbiological sulfate removal design is the selection of the substrate, which supplies electrons, carbon, and nutrients. For passive systems, solid and usually waste-based substrates are used, while active systems employ liquid or gaseous materials. Suitable substrates have been reviewed by, for instance, Liamleam and Annachhatre (2007) and Dev et al. (2015). The selection should be based on the treatment efficiency (the reduction of sulfate and minimizing the occurrence of other pollutants) and the cost per unit sulfate converted into sulfide (Liamleam and Annachhatre 2007). Complex electron donors, such as molasses or hydrocarbons, tend to remain incompletely oxidized and thus increase the COD content in treated effluent (Liamleam and Annachhatre 2007). Ethanol has been deemed the most cost-effective when treating $<200 \mathrm{~kg} \mathrm{SO}_{4}{ }^{2-} / \mathrm{h}$, while hydrogen gas becomes competitive at higher loadings (Liamleam and Annachhatre 2007). Hay was found to provide more dissolved organic carbon (and thus achieve a higher sulfate reduction rate) than wood, whereas manure addition was deemed to be unnecessary (Mirjafari and Baldwin 2016).

Table 2 summarizes recent studies in which SRB are used for sulfate and usually coexisting metal removal from AMD. As can be seen, microbial sulfate removal has potential to reach very low sulfate levels $\left(<100 \mathrm{mg} \mathrm{L}^{-1}\right)$. However, a disadvantage is the required long hydraulic retention time, which can prevent treating large flow rates, or, alternatively, several parallel units are required. Microbial sulfate removal by SRB is utilized in some commercialized processes, for instance, Rhodes BioSURE (capacity $10000 \mathrm{~m}^{3} / \mathrm{d}$, wastewater sludge as substrate, HRT $12 \mathrm{~h}$, sulfate after treatment $<100 \mathrm{mg}$ $\mathrm{L}^{-1}$ ) (Rose 2013) or THIOPAQ (synthesis gas as substrate, several different size full-scale installations exist for sulfate/metal removal) (Buisman et al., 1999). An interesting alternative approach was taken by Li et al. (2017), who utilized SRB and other microbes to remove metals and COD, respectively, from landfill leachate using AMD as a sulfate source. They were also able to produce methane due to coexisting methane producing bacteria and $\mathrm{SRB}\left(\mathrm{COD} / \mathrm{SO}_{4}{ }^{2-}\right.$ weight ratio was optimally 3.0) (Li et al., 2017). 


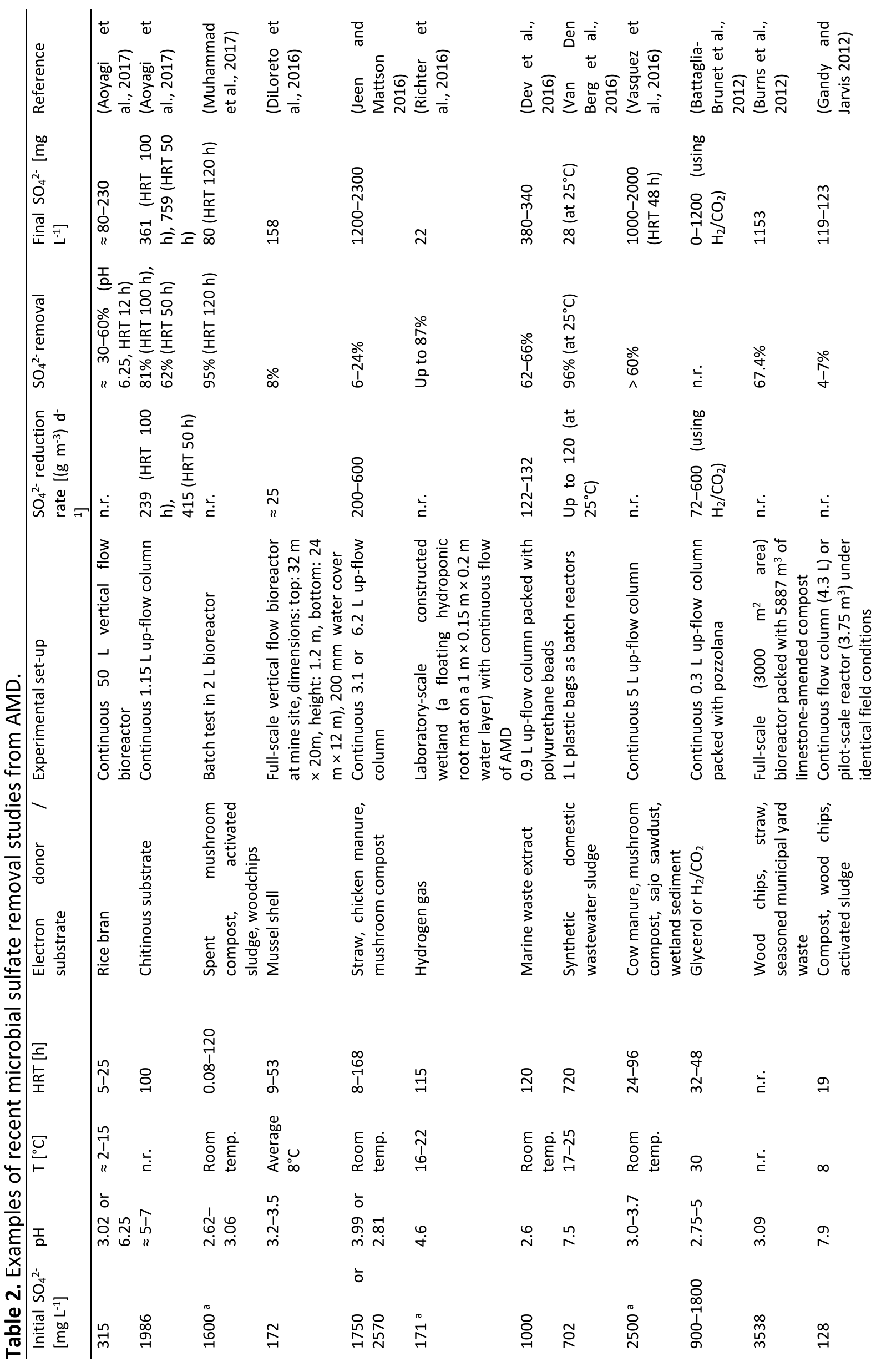




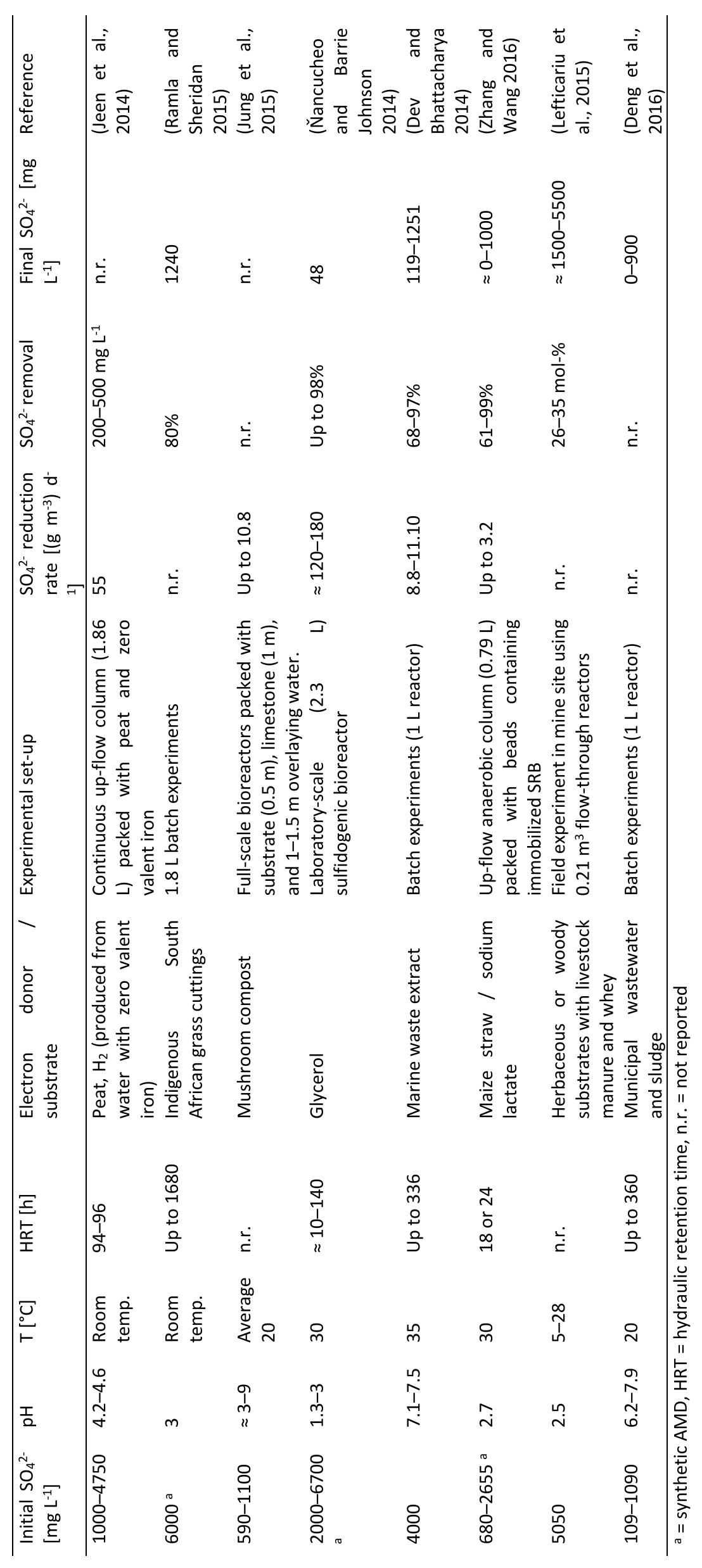


Microbial fuel cells (MFCs) are a novel method for removing sulfate from AMD. A review of their operational principles and design is provided, for instance, by Du et al. (2007). In short, in a conventional two-chamber MFC, bacteria catalyze the oxidation of organic or inorganic electron donors at the anode, the electrons are transferred to the cathode via an external circuit, and at the cathode other bacteria species utilize the electrons for reduction reactions, such as sulfate reduction (Logan et al., 2006; Rabaey and Rozendal 2010; Rosenbaum et al., 2011; Su et al., 2012). When used for sulfate removal, both one- and two-chamber MFC set-ups have been studied. MFCs could be designed to contain an autotrophic biocathode in which the SRB use $\mathrm{CO}_{2}$ as the carbon source and the SRB consist of an acidophilic strain, which potentially removes the need to adjust the $\mathrm{pH}$ before treatment (Coma et al., 2013; Teng et al., 2016). MFCs also have potential to produce electricity directly from chemical energy, but the power generation is still inefficient (Du et al., 2007).

Tang et al. (2016) reported that their MFCs were able to remove $51.2 \%, 39.8 \%$, and $33.1 \%$ of sulfate from 1000, 2000, and $3000 \mathrm{mg} \mathrm{L}^{-1} \mathrm{SO}_{4}{ }^{2-}$ concentrations, respectively, using a 48-hour hydraulic retention time and activated sludge as a substrate. They were also able to generate up to approximately $230 \mathrm{mV}$ voltage, which decreased to approximately $50 \mathrm{mV}$ after 15 days of operation (Tang et al., 2016). Teng et al. (2016) reported up to approximately $40 \%$ sulfate removal from a 200 $\mathrm{mg} \mathrm{L}^{-1} \mathrm{SO}_{4}{ }^{2-}$ initial concentration with a two-chamber MFC. The current density produced by their MFC was up to $50 \mathrm{~A} \mathrm{~m}^{-3}$, from which it gradually decreased during operation (Teng et al., 2016). Peng et al. (2017) were able to remove up to $71 \%$ of the sulfate (from $3000 \mathrm{mg} \mathrm{L}^{-1}$ in synthetic AMD) and generate $51.3 \mathrm{~mW} \mathrm{~m}^{-2}$ power density from their MFC using wastewater sludge as a substrate. Lee et al. $(2012,2014)$ used a combination of SRB and sulfide-oxidizing bacteria biofilms on an MFC anode, and the generated sulfide was converted irreversibly to elemental sulfur. Finally, Zhao et al. (2008) used activated carbon cloth as anode material in their MFC and achieved up to $99 \%$ sulfate removal (from approx. $3000 \mathrm{mg} \mathrm{L}^{-1} \mathrm{SO}_{4}{ }^{2-}$ ). However, the technology readiness level of MFCs is still rather low.

\subsection{Membrane technology}

Pressure-driven membranes are conventionally classified as microfiltration, ultrafiltration, nanofiltration (NF), and reverse osmosis (RO), depending on their separation capacity. Of these classes, NF and RO are suitable for sulfate rejection as they can effectively separate divalent and monovalent ions, respectively. In general, both NF and RO have demonstrated high efficiency for sulfate removal, achieving over 99\% rejection in ideal conditions (Ambiado et al., 2017; Aubel et al., 2017; Bodalo et al., 2004; Visser et al., 2011). Consequently, NF- or RO-based mine water treatment allows the attainment of even the most stringent sulfate discharge limits or reuse permeate in processes with high water quality requirements. In practice, however, NF is the more appropriate choice for mine water treatment due to lower energy consumption and operational costs compared to RO but still with excellent permeate quality (Al-Zoubi et al., 2010). It should be noted, though, that the energy consumption is strongly affected by the feed concentration of dissolved solids and subsequently required osmotic pressure (Ghalavand et al., 2015)

The feed water sulfate concentration for membranes can be relatively high; for instance, Bódalo et al. (2004) used a commercial cellulose acetate RO membrane (SEPA-SS1C, Osmonics) to treat sulfate concentrations up to $25000 \mathrm{mg} \mathrm{L}^{-1}$ and obtained $99.6 \%$ rejection. However, other water quality parameters (Table 3) need to be carefully controlled or various types of membrane fouling and/or scaling can occur. The build-up of suspended and dissolved solids on the membrane surface is caused 
by the concentration polarization: the hydraulic flow along the membrane surface creates a boundary layer in which the convective flow toward the membrane is faster than the back diffusion away from the membrane (Flynn 2009). Fouling and scaling causes operational costs to increase due to an increased need for chemical cleaning and anti-scalant use, decreased membrane service life, and lowered water recovery (Goh et al., 2018; Jiang et al., 2017; Landaburu-Aguirre et al. 2016; Shirazi et al., 2010). In practice, the lower feed water quality also decreases the flux (amount of water passing through a given membrane area per unit of time) that can be used (Flynn 2009). The feed water pretreatment represents a significant fraction of a desalination plant's total capital costs: up to $20 \%$ (Sutzkover-Gutman and Hasson 2010). As an example of the innovative pre-treatment of AMD, Masindi et al. (2017) used basic oxygen furnace (BOF) slag, lime, and soda ash before RO and were able to recover drinking quality water. In their study, the sulfate concentrations were 18000,4570 , 200,20 , and $0.19 \mathrm{mg} \mathrm{L}^{-1}$ as initially, after BOF slag, lime treatment, $\mathrm{Na}_{2} \mathrm{CO}_{3}$ treatment, and $\mathrm{RO}$, respectively. Another recently demonstrated pre-treatment scheme involved caustic soda followed by ozone to remove especially Fe(II) and $\mathrm{Mn}$ (II) from coal mine drainage (Boyden et al., 2017). The use of microfiltration before NF or RO is also a feasible option (Kyllönen et al., 2017).

Table 3. General feed water pre-treatment requirements for NF and RO membranes (Flynn 2009; Sutzkover-Gutman and Hasson 2010).

\begin{tabular}{|c|c|}
\hline \multicolumn{2}{|c|}{ Feed water pre-treatment requirements for NF and RO } \\
\hline Silt density index & $<5$ \\
\hline Turbidity [NTU] & $<1$ \\
\hline $\mathrm{TOC}\left[\mathrm{mg} \mathrm{L}^{-1}\right]$ & $<3$ \\
\hline Color [APHA color units] & $<3$ \\
\hline Metals: $\mathrm{Fe}, \mathrm{Mn}, \mathrm{Al}\left[\mathrm{mg} \mathrm{L}^{-1}\right]$ & $<0.05$ \\
\hline Hydrogen sulfide $\left[\mathrm{mg} \mathrm{L}^{-1}\right]$ & $<0.1$ \\
\hline Oil and grease $\left[\mathrm{mg} \mathrm{L}^{-1}\right]$ & $<0.1-0.5$ \\
\hline Bacterial count [CFU mL $\mathrm{mL}^{-1}$ ] & $<1000$ \\
\hline
\end{tabular}

The water recovery (i.e., the amount of pure water or permeate) of NF or RO varies within $50-90 \%$ of the total treated water volume, and thus the concentrate (i.e., rejectate or brine) requires further treatment and management (see section 3.6 for further details) (Flynn 2009; Giwa et al., 2017). As can be seen from Table 4, the typical water recoveries have varied between $60-70 \%$ in recent studies.

The most common NF or RO membrane materials are asymmetric cellulose acetate or polyamide composites (Flynn 2009). The latter are also referred to as thin-film composite, and they consist of support, polysulfone backing, and a polyamide or polypiperazide layer (Flynn 2009). The general difference is that cellulose acetate membranes are more resistant to fouling, whereas polyamide composites typically exhibit higher rejection (Flynn 2009). Furthermore, polyamide composite membranes have a negative charge, implying higher sulfate rejection than neutral-charged cellulose acetate membranes (Flynn 2009; Mullett et al., 2004). Membrane characteristics, such as thermal, mechanical, and chemical properties, affect the operational efficiency. Chemical modifications can be implemented to alter surface charge, hydrophilicity, roughness, or permeability to improve their properties. One attempt was made by Juholin et al. (2018), who coated a commercial NF membrane (NF270, Dow) with ZnO using atomic layer deposition for the treatment of real mine wastewaters. They observed that reversible fouling decreased (while irreversible fouling was not affected) and that relative flux possibly increased slightly when compared to membranes without coating (NF90 and 
NF270, Dow). However, there was Zn leaching into the permeate from the coating, and the sulfate rejection remained unchanged at $>91 \%$.

Table 4. Recent mine effluent treatment studies with NF or RO.

\begin{tabular}{|c|c|c|c|c|c|c|c|c|}
\hline $\begin{array}{l}\mathrm{SO}_{4}^{2-} \\
{\left[\mathrm{mg} \mathrm{L}^{-1}\right]}\end{array}$ & $\mathrm{pH}$ & $\begin{array}{l}\text { Membrane } \\
\text { (commercial name) }\end{array}$ & $\begin{array}{l}\text { Pressure } \\
\text { [bar] }\end{array}$ & $\begin{array}{l}\text { Flowrate } \\
{\left[\mathrm{m}^{3} \mathrm{~h}^{-1}\right]}\end{array}$ & $\begin{array}{l}\text { Flux }\left[\mathrm{L} \mathrm{h}^{-1}\right. \\
\left.\mathrm{m}^{-2}\right]\end{array}$ & $\begin{array}{l}\text { Water } \\
\text { recovery [\%] }\end{array}$ & $\begin{array}{l}\text { Sulfate rejection } \\
\text { [\%] }\end{array}$ & Reference \\
\hline $\begin{array}{l}2000- \\
2800\end{array}$ & $\begin{array}{l}3.4- \\
3.8\end{array}$ & $\mathrm{NF} 270^{\mathrm{a}}$ & 10 & 0.14 & 25 (avg.) & 60 & 87 & Aguiar et al., 2018 \\
\hline 790 & 5.6 & NF270 a & 10 & 0.79 & n.r. & 57 & 88 & Wadekar et al., 2017 \\
\hline $\begin{array}{l}6900- \\
10500\end{array}$ & $\begin{array}{l}2.6- \\
5.5\end{array}$ & NF270 a & $7-20$ & $\begin{array}{l}0.200- \\
0.225\end{array}$ & $32-34$ & 70 & $\approx 87-97$ & Mullett et al., 2014 \\
\hline 790 & 5.6 & $\mathrm{NFHL}^{\mathrm{a}}$ & 10 & 0.79 & n.r. & 57 & 81 & Wadekar et al., 2017 \\
\hline 790 & 5.6 & XN45 a & 10 & 0.79 & n.r. & 57 & 88 & Wadekar et al., 2017 \\
\hline $\begin{array}{l}6900- \\
10500\end{array}$ & $\begin{array}{l}2.6- \\
5.5\end{array}$ & TriSep TS80 ${ }^{b}$ & $10-23$ & $\begin{array}{l}0.200- \\
0.225\end{array}$ & $32-35$ & 70 & $\approx 95-98$ & Mullett et al., 2014 \\
\hline 2620 & 2.1 & $\mathrm{NF90}{ }^{\mathrm{b}}$ & $\approx 8$ & 0.144 & $10-60$ & 70 & 94 & Andrade et al., 2017 \\
\hline 3500 & 2.2 & $\mathrm{NF90}{ }^{\mathrm{b}}$ & 10 & n.r. & $15-40$ & n.r. & 96 & Agboola et al., 2017 \\
\hline 790 & 5.6 & $\mathrm{NF90}{ }^{\mathrm{b}}$ & 10 & 0.79 & n.r. & 57 & 88 & Wadekar et al., 2017 \\
\hline 3500 & 2.2 & Nano-Pro-3012 b & 10 & n.r. & $10-23$ & n.r. & 86 & Agboola et al., 2017 \\
\hline 790 & 5.6 & $N F X^{b}$ & 10 & 0.79 & n.r. & 57 & 90 & Wadekar et al., 2017 \\
\hline 790 & 5.6 & NFW ${ }^{b}$ & 10 & 0.79 & n.r. & 57 & 80 & Wadekar et al., 2017 \\
\hline 790 & 5.6 & $N F{ }^{b}$ & 10 & 0.79 & n.r. & 57 & 20 & Wadekar et al., 2017 \\
\hline 790 & 5.6 & $\mathrm{NFCK}^{\mathrm{c}}$ & 10 & 0.79 & n.r. & 57 & 90 & Wadekar et al., 2017 \\
\hline
\end{tabular}

In addition to the conventional pressure-driven membrane processes described above, other membrane techniques have also been applied for mine effluents. Electrodialysis (ED) is a membrane process in which the selective transport of ions through charged membranes is caused by applying an electrical field (Mulder 1998). Anion-exchange membranes contain positively charged groups and cation-exchange membranes negatively charged groups (Mulder 1998). Typically a series of anionand cation-exchange membranes are placed between an anode and a cathode to form an ED cell. Negatively charged sulfates will migrate toward the positively charged anode when an electrical field is applied (Mulder 1998; Buzzi et al., 2013). One diluted and one concentrated effluent are formed during ED treatment (Buzzi et al., 2013). Buzzi et al. (2013) have used ED to treat AMD with 518-7399 $\mathrm{mg} \mathrm{L}^{-1}$ sulfate content with $98-99 \%$ sulfate extraction efficiency.

Membrane distillation utilizes temperature difference, and subsequent vapor pressure difference, across a hydrophobic membrane as the driving force: vapor molecules are transported through the membrane while dissolved solids are retained (Alkhudhiri et al., 2017). The use of membrane distillation was demonstrated with synthetic AMD: $>99 \%$ TDS rejection was obtained with $80 \%$ water recovery, flux of $38 \mathrm{~L} / \mathrm{m}^{2} / \mathrm{h}$, and a $34^{\circ} \mathrm{C}$ temperature difference (Hull and Zodrow 2017). The relatively low temperature difference suggests that membrane distillation could be utilized with geothermal energy or other low-grade heat sources (Hull and Zodrow 2017).

\subsection{Concentrate treatment and recovery of sulfur chemicals}

Several of the discussed processes (ion exchange, adsorption, and membrane technologies) result in the formation of concentrated effluent (i.e., concentrate or reject water). In the case of membrane separation, the reject water sulfate concentration can be calculated with Equation 27 (Flynn 2009): Reject water $\mathrm{SO}_{4}^{2-}\left(\frac{m g}{L}\right)=\frac{\text { Feed flow rate }\left(\frac{m^{3}}{h}\right)}{\text { Reject flow rate }\left(\frac{m^{3}}{h}\right)} \times$ Feed water $\mathrm{SO}_{4}^{2-}\left(\frac{m g}{L}\right)$

Concentrate treatment is an essential issue when considering the feasibility of the discussed processes. For instance, membrane processes result typically approximately $40 \%$ concentrate of the 
feed water volume (Banerjee et al., 2015). To increase utilization possibilities of concentrates, they need to be further concentrated. One method is through multiple membrane filtration stages: for instance, a two-stage RO process has been used for years (Morillo et al., 2014).

One still research-level method is the use of forward osmosis (FO), in which the concentration difference across a semipermeable membrane is the driving force. In short, water passes from the concentrate through the membrane to the draw solution (which has a higher concentration than the concentrate). Due to the very low hydraulic pressure required, FO is expected to deliver many potential advantages, such as less energy input, lower fouling tendency, easier fouling removal, and higher water recoveries over pressure-driven processes (Akther et al., 2015).

ED is currently being studied as a another option to concentrate RO rejects and to obtain solid salts that can be further reused (Casas et al., 2012). Sulfuric acid can be produced from AMD with ED (Mulder 1998, Martí-Calatayud et al. 2014). Nleya et a. (2016) have reviewed technologies for the recovery of acid from wastewaters.

Freeze crystallization (FC) is a possible method for the concentration of concentrated effluents produced in the membrane processes (Randall and Nathoo 2015). In FC, effluent is cooled below the freezing point of water, and water crystallizes into ice concentrating the effluent (Naidu et al., 2018; Randall and Nathoo 2015). Eutectic freeze crystallization (EFC) is an extended FC process that enables the recovery of salt and pure water from effluents. When effluent is cooled down to its eutectic point, ice and salt crystallize simultaneously, and, by utilising their density difference, separation is possible (Hasan et al., 2017). Furthermore, if the system contains multiple salts, each is formed at its characteristic crystallization temperature and no problematic mixture of salts is obtained. EFC is also advantageous in regard to energy consumption: the heat of fusion $\left(6.01 \mathrm{~kJ} \mathrm{~mol}^{-1}\right)$ is lower than the heat of the vaporization ( $40.65 \mathrm{~kJ} \mathrm{~mol}^{-1}$ ) of water (Pérez-González et al., 2012). EFC has been tested for the full-scale process, for instance, for the treatment of RO brine (Randall et al., 2011).

The chemically-enhanced seeded precipitation (CESP) of RO concentrate has also been studied (McCool et al., 2013). In CESP, gypsum seeds are added to supersaturated lime pre-treated RO concentrate to induce gypsum precipitation (McCool et al., 2013). McCool et al. (2013) have stated that a $93 \%$ desalting recovery of RO concentrate with CESP could be possible. Aube and Lee (2015) have suggested the use of the high-density-sludge process for NF and RO concentrate treatment. Evaporation is used for RO concentrate treatment (Khan et al., 2009). The simplest evaporation method is solar evaporation, in which the brine is left in an evaporation pond, where the water evaporates and salt is left (Morillo et al., 2014). However, evaporation ponds need large land areas, hot and dry conditions, and need to be constructed properly to avoid seepage (Khan et al., 2009). Also, water recovery is not possible with solar evaporation (Vane 2017). With other evaporation techniques water is vaporized from the concentrate and can be subsequently recovered with condensation (Kim 2011). Evaporation technologies are energy intensive, and enhanced evaporation techniques, such as thermal vapor compression and mechanical vapor compression for minimizing energy consumption, have been developed (Khan et al., 2009; Subramani et al., 2014; Vane 2017,).

The treatment of concentrate using membrane distillation (MD) has also been proposed (Naidu et al., 2018). Water vapor is transported through a hydrophobic membrane in the thermal-based MD process (Naidu et al., 2018). However, scaling caused by inorganic ion precipitation on the membrane surface has been reported (Naidu et al., 2018). 
Mulopo(2016) has studied elemental sulfur recovery from AMD through thermal reduction of $\mathrm{BaSO}_{4} / \mathrm{CaCO}_{3}$ and $\mathrm{CaSO}_{4} / \mathrm{Mg}(\mathrm{OH})_{2}$ sludges to barium and calcium sulfide and the stripping of the sulfide with $\mathrm{CO}_{2}$ gas to produce sulfur.

\section{Conclusions}

Sulfate is a commonly occurring major anion that is not considered toxic as such. Nevertheless, it can possess threads, especially to freshwater biota, when present in excessive amounts. One important point source of sulfate release in aquatic environments are mines. The currently practiced gypsum precipitation is capable of reducing sulfate down to approximately $2000 \mathrm{mg} \mathrm{L}^{-1}$ as the theoretical minimum. However, this is not enough for the most stringent environmental requirements, which are as low as $10 \mathrm{mg} \mathrm{L}^{-1}$ in an extreme case, and therefore more efficient treatment means are needed. The discussed alternatives in this review were alternative precipitation methods, adsorption, ion exchange, biological treatment, and membrane technologies. In addition, the further treatment of concentrate, which is formed in many of the aforementioned processes, was overviewed.

Ettringite and barite are alternative low-solubility minerals that sulfate can be precipitated into to reach sulfate levels down to $200 \mathrm{mg} \mathrm{L}^{-1}$ or less. Both processes use more expensive chemicals compared to gypsum precipitation, but the formed precipitates can be recycled to decrease operational costs. In the case of barite precipitation, however, the barium salts are also significantly toxic. Sludge as the secondary waste from these processes needs to be properly managed and ideally reclaimed. The third alternative precipitation process involves the formation of jarosite, but the harsh

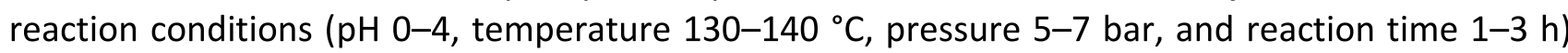
required make this option unfeasible.

Adsorption has been performed with a number of experimental materials with or without chemical modifications. However, no fully commercialized processes exist yet. The most likely application area would be as a polishing method after pre-treatment in the case where a very low sulfate level is required. In the process, sulfate is bound to a solid adsorbent, which needs to be regenerable, for several times, to be economically feasibility. The secondary waste is therefore a concentrate from regeneration containing sulfate and regenerant. Other key issues are the capacity and selectivity of the adsorbent for sulfate. Thus far, the highest reported theoretical adsorption capacities are approximately $280 \mathrm{mg} \mathrm{g}^{-1}$. This means that, even in this ideal case, the removal of, for instance, 500 $\mathrm{mg} \mathrm{L}^{-1}$ of sulfate would require an adsorbent dose of $1.8 \mathrm{~g} \mathrm{~L}^{-1}$; that is $180 \mathrm{~kg}$ of adsorbent per hour for $100 \mathrm{~m}^{3} \mathrm{~h}^{-1}$ flow rate, as an example. This clearly demonstrates the need for regeneration.

Weak base anion resins are typically used in sulfate removal. Ion exchange may not be suitable as a primary technology, but it has potential to be used in combination with other processes. The CYP-CIX process is effective for sulfate removal at the concentration near the gypsum saturation level.

Biological treatment involves SRB, which convert sulfate into sulfide. Sulfide can be further precipitated with metals, and ideally the product can be reclaimed. The process can be implemented as passive or active, which indicates whether the substrate (electron, nutrient, and carbon source) is supplied as a batch lasting for several years or continuously, respectively. The active treatment results in a more predictable performance, but the operational costs are higher than with passive systems. Biological treatment systems have been demonstrated to be operational even in cold 
conditions, and the reachable sulfate concentration is down to approximately $100 \mathrm{mg} \mathrm{L}^{-1}$. However, the downside is the required long contact time of several or even tens of hours. One interesting application of biological treatment are the microbial fuel cells (MCFs) that have the potential of generating electricity during treatment. MFCs, though, are not yet commercially available.

Membrane technologies capable of rejecting sulfate from mine water sufficiently to reach even the most stringent sulfate discharge are NF, RO, and ED. The quality of the permeate enables its reuse in process. Even $25000 \mathrm{mg} \mathrm{L}^{-1}$ concentrations can be treated by using a commercial RO membrane, and over $99 \%$ rejections can be achieved in ideal conditions. Water quality needs to be controlled to prevent membrane fouling and/or scaling, to ensure sufficient water flux, and to lower energy consumption. Feed water pre-treatment causes up to $20 \%$ of capital costs.

Ion exchange, adsorption, and membrane technologies form concentrates whose treatment has to be taken into account to consider the feasibility of these processes. The volume of concentrate can be reduced through multiple membrane filtration stages, for instance, with the two-stage RO process. Concentrate treatment can be done with membrane technologies, crystallization, or thermal processes.

As a final remark, it can be concluded that reaching concentrations clearly lower than those with gypsum precipitation $\left(\approx 1500 \mathrm{mg} \mathrm{L}^{-1}\right)$ is definitely possible with commercially available technology. However, all the methods still have unresolved issues, at least in terms of cost-efficiency, compared to gypsum precipitation. Nevertheless, gypsum precipitation will still have an important role as the first process step in mine effluent treatment, and more advanced methods can be used as polishing steps.

\section{Acknowledgements}

This work was in part supported by the Finnish Funding Agency for Innovation (TEKES) under Grant 4096/31/2014 (project GeoSorbents) and Maa-ja vesitekniikan tuki ry.

\section{References}

Aalto, J.M., Kankkunen, J., Vepsäläinen, J., 2017. Removal of sulfur substances from an aqueous medium with a solid material. Patent application WO2017037335A1.

Adlem, C.J.L., Maree, J.P., Du Plessis, P., 1991. Treatment of sulphate-rich mining effluents with the barium hydroxide process and recovery of valuable by-products. $4^{\text {th }}$ International Mineral Water Association Congress, International Mine Water Association. https://www.imwa.info/docs/imwa_1991/IMWA1991_Adlem_211.pdf.

Agboola, O., Mokrani, T., Sadiku, E.R., Kolesnikov, A., Olukunle, O.I., Maree, J.P., 2017. Characterization of two nanofiltration membranes for the separation of ions from acid mine Water. Mine Water Environ. 36, 401-408. http://dx.doi.org/10.1007/s10230-016-0427-z. 
Aguiar, A., Andrade, L., Grossi, L., Pires, W., Amaral, M., 2018. Acid mine drainage treatment by nanofiltration: A study of membrane fouling, chemical cleaning, and membrane ageing. Sep. Purif. Technol. 192, 185-195. https://doi.org/10.1016/j.seppur.2017.09.043.

Akther, N., Sodiq, A., Giwa, A., Daer, S., Arafat, H.A., Hasan, S.W., 2015. Recent advancements in forward osmosis desalination: A review. Chem. Eng. J. 281, 502-522. http://dx.doi.org/10.1016/j.cej.2015.05.080.

Alakangas, L., Andersson, E., Mueller, S., 2013. Neutralization/prevention of acid rock drainage using mixtures of alkaline by-products and sulfidic mine wastes. Environ. Sci. Pollut. Res. 20, 79077916. http://dx.doi.org/10.1007/s11356-013-1838-z.

Alkhudhiri, A., Darwish, N., Hilal, N., 2012. Membrane distillation: A comprehensive review. Desalination 287, 2-18. https://doi.org/10.1016/j.desal.2011.08.027.

Al-Tayyib, A.J., Shamim Khan, M., 1991. Effect of sulfate ions on the corrosion of rebars embedded in concrete. Cem. Concr. Compos. 13, 123-127. https://doi.org/10.1016/0958-9465(91)90007-5.

Álvarez-Ayuso, E., Nugteren, H.W., 2005. Synthesis of ettringite: a way to deal with the acid wastewaters of aluminium anodising industry. Water Res. 39, 65-72. https://doi.org/10.1016/j.watres.2004.07.029.

Alves, M.E., Lavorenti, A., 2004. Sulfate adsorption and its relationships with properties of representative soils of the São Paulo State, Brazil. Geoderma 118, 89-99. http://dx.doi.org/10.1016/S0016-7061(03)00186-1.

Al-Zoubi, H., Rieger, A., Steinberger, P., Pelz, W., Haseneder, R., Härtel, G., 2010. Optimization study for treatment of acid mine drainage using membrane technology, Sep. Sci. Technol. 45. https://doi.org/10.1080/01496395.2010.480963.

Ambiado, K., Bustos, C., Schwarz, A., Bórquez R., 2017. Membrane technology applied to acid mine drainage from copper mining. Water Sci. Technol. 75, 705-715. https://doi.org/10.2166/wst.2016.556.

Andrade, L.H., Ricci, B.C., Grossi, L.B., Pires, W.L., Aguiar, A.O., Amaral, M.C.S., 2017. Nanofiltration applied in gold mining effluent treatment: Evaluation of chemical cleaning and membrane stability. Chem. Eng. J. 323, 545-556. https://doi.org/10.1016/j.cej.2017.04.116.

Aoyagi, T., Hamai, T., Hori, T., Sato, Y., Kobayashi, M., Sato, Y., Inaba, T., Ogata, A., Habe, H., Sakata, T., 2017. Hydraulic retention time and $\mathrm{pH}$ affect the performance and microbial communities of passive bioreactors for treatment of acid mine drainage. AMB Express 7, 142. http://dx.doi.org/10.1186/s13568-017-0440-z.

Aubé, B., Lee, D., 2015. The High Density Sludge (HDS) Process and Sulphate Control. 10th International Conference on Acid Rock Drainage \& IMWA Annual Conference. https://www.imwa.info/docs/imwa_2015/IMWA2015_Aube_188.pdf. 
Aubel. T., Janneck, R., Kalanchey, R., 2017. Process development for complex mine water treatment. Lappeenranta, Finland IMWA 2017 Mine Water and Circular Economy Wolkersdorfer C, Sartz L, Sillanpää $M$, Häkkinen $A$ (Editors).

Auvinen, H., Nevatalo, L.M., Kaksonen, A.H., Puhakka, J.A., 2009. Low-temperature $\left(9^{\circ} \mathrm{C}\right)$ AMD treatment in a sulfidogenic bioreactor dominated by a mesophilic Desulfomicrobium species. Biotechnol. Bioeng. 104, 740-751. http://dx.doi.org/10.1002/bit.22434.

Baldwin, S.A., Mattes, A., Rezadehbashi, M., Taylor, J., 2016. Seasonal microbial population shifts in a bioremediation system treating metal and sulfate-rich seepage. Minerals 6, 36. http://dx.doi.org/10.3390/min6020036.

Banerjee K., Howell C., Blumenschein C., Buisson H., 2015. An innovative process to reduce sulfate in membrane concentrate enhances mine water recovery. $10^{\text {th }}$ International Conference on Acid Rock Drainage \& IMWA Annual Conference. http://www.imwa.info/docs/imwa_2015/IMWA2015_Banerjee_203.pdf

Barton, L.L., Hamilton, W.A., 2007. Sulphate-reducing bacteria: Environmental and engineered systems, Cambridge University Press, Cambridge.

Barton, L., Fauque, G., 2009. Chapter 2 Biochemistry, physiology and biotechnology of sulfatereducing bacteria. Adv. Appl. Microbiol. 68, 41-98. https://doi.org/10.1016/S00652164(09)01202-7.

Battaglia-Brunet, F., Crouzet, C., Burnol, A., Coulon, S., Morin, D., Joulian, C., 2012. Precipitation of arsenic sulphide from acidic water in a fixed-film bioreactor. Water Res. 46, 3923-3933. http://dx.doi.org/10.1016/j.watres.2012.04.035.

Bazer-Bachi, F., Descostes, M., Tevissen, E., Meier, P., Grenut, B., Simonnot, M.-O., Sardin, M., 2007. Characterization of sulphate sorption on Callovo-Oxfordian argillites by batch, column and through-diffusion experiments. Physics and Chemistry of the Earth, Parts A/B/C 32, 552-558. http://dx..org.pc124152.oulu.fi:8080/10.1016/j.pce.2006.01.010.

Benatti, C.T., Tavares, C.R.G., Lenzi, E., 2009. Sulfate removal from waste chemicals by precipitation. J. Environ. Manage. 90, 504-511. https://doi.org/10.1016/j.jenvman.2007.12.006.

Bernardez, L.A., de Andrade Lima, L.R.P., Ramos, C.L.S., Almeida, P.F., 2012. A Kinetic analysis of microbial sulfate reduction in an upflow packed-bed anaerobic bioreactor. Mine Water Environ. 31, 62-68. http://dx.doi.org/10.1007/s10230-012-0170-z.

Bijmans, M.F.M., 2008. Sulfate reduction under acidic conditions for selective model recovery. University. Promotor(en): Cees Buisman, co-promotor(en): Piet Lens. - [S.I.] : S.n. - ISBN 9789085049258 - 156 p. http://library.wur.nl/WebQuery/wurpubs/366325.

Bódalo, A., Gómez, J., Gómez, E., León, G., Tejera, M., 2004. Reduction of sulphate content in aqueous solutions by reverse osmosis using cellulose acetate membranes. Desalination 162, 55-60. https://doi.org/10.1016/S0011-9164(04)00027-X. 
Bologo, V., Maree, J.P., Carlsson, F. 2012. Application of magnesium hydroxide and barium hydroxide for the removal of metals and sulphate from mine water. Water SA 38, http://www.scielo.org.za/scielo.php?script=sci_arttext\&pid=S1816-79502012000100004.

Bomberg, M., Arnold, M., Kinnunen, P., 2015. Characterization of the bacterial and sulphate reducing community in the alkaline and constantly cold water of the closed Kotalahti Mine. Minerals 5, 452-472. http://dx.doi.org/10.3390/min5030452.

Bosman, D.J., Clayton, J.A., Maree, J.P., Adlem, C.J.L., 1990. Removal of sulphate from mine water with barium sulphide. Int. J. Mine Water 9, 149-163. https://doi.org/10.1007/BF02503689.

Boyden, B.H., Nador, L., Addleman, S., Jeston L., 2017. The economic pre-treatment of coal mine drainage water with caustic and ozone. Water Sci. Technol. 76, 1022-1034. https://dx.doi.org/ 10.2166/wst.2017.263.

Brown, M., Barley, B., Wood, H., 2002. Minewater treatment: Technology, Application and Policy, IWA Publishing, London.

Buisman, C., Vellinga, S., Janssen, G., Dijkman, H., Paques, B., 1999. Biological Sulfide Production for Metal Recovery. EPD Congress.

Burns, A.S., Pugh, C.W., Segid, Y.T., Behum, P.T., Lefticariu, L., Bender, K.S., 2012. Performance and microbial community dynamics of a sulfate-reducing bioreactor treating coal generated acid mine drainage. Biodegradation 23, 415-429. http://dx.doi.org/10.1007/s10532-011-9520-y.

Buzzi, D.C., Viegas, L.S., Rodrigues, M.A.S., Bernardes, A.M., Tenório, J.A.S., 2013. Water recovery from acid mine drainage by electrodialysis. Minerals Eng. 40, 82-89. http://dx.doi.org/10.1016/j.mineng.2012.08.005.

Cañedo-Argüelles, M., Kefford, B.J., Piscart, C., Prat, N., Schäfer, R.B., Schulz, C.-J., 2013. Salinisation of rivers: An urgent ecological issue. Environ. Pollut. 173: 157-167. https://doi.org/10.1016/j.envpol.2012.10.011.

Cao, W., Dang, Z., Zhou, X., Yi, X., Wu, P., Zhu, N., Lu, G., 2011. Removal of sulphate from aqueous solution using modified rice straw: Preparation, characterization and adsorption performance. Carbohydr. Polym. 85, 571-577. https://doi.org/10.1016/j.carbpol.2011.03.016.

Casas, S., Aladjem, C., Cortina, J.L., Larrotcha, E., Cremades, L.V., 2012. Seawater reverse osmosis brines as a new salt source for the chlor-alkali industry: Integration of $\mathrm{NaCl}$ concentration by electrodialysis. Solv. $\quad$ Extr. Ion 322-332. http://dx.doi.org/10.1080/07366299.2012.686849.

Chen, X., Yao, P., Wang, D., Wu, X., 2009. Antimony and cerium co-doped tin oxide electrodes for pollutant degradation. Chem. Eng. J. 147, 412-415. https://doi.org/10.1016/j.cej.2008.10.025.

Clescerl, L.S., Greenberg, A.E., Eaton, A.D. (Eds), 1999. Standard Methods for Examination of Water \& Wastewater, American Public Health Association, American Water Works Association, Water Environment Federation, Washington, DC. 
Cocchetto, D.M., Levy, G., 1981. Absorption of orally administered sodium sulfate in humans. J. Pharm. Sci. 70, 331-333. http://dx.doi.org/10.1002/jps.2600700330.

Coma, M., Puig, S., Pous, N., Balaguer, M.D., Colprim, J., 2013. Biocatalysed sulphate removal in a BES cathode. Bioresour. Technol. 130, 218-223. http://dx.doi.org/10.1016/j.biortech.2012.12.050.

de la Torre, M.L., Grande, J.A., Graiño, J., Gómez, T., Cerón, J.C., 2011. Characterization of AMD pollution in the river Tinto (SW Spain). Geochemical comparison between generating source and receiving environment. Wat. Air Soil Pollut. 216, 3-19. http://dx.doi.org/10.1007/s11270-0100510-1.

Dehwah, H.A.F., Maslehuddin, M., Austin, S.A., 2002. Long-term effect of sulfate ions and associated cation type on chloride-induced reinforcement corrosion in Portland cement concretes. Cem. Conc. Comp. 24, 17-25. https://doi.org/10.1016/S0958-9465(01)00023-3.

Delfosse, T., Delmelle, P., Delvaux, B., 2006. Sulphate sorption at high equilibrium concentration in Andosols. Geoderma 136, 716-722. https://doi.org/10.1016/j.geoderma.2006.05.009.

Deng, D., Weidhaas, J.L., Lin, L.-S., 2016. Kinetics and microbial ecology of batch sulfidogenic bioreactors for co-treatment of municipal wastewater and acid mine drainage. J. Hazard. Mater. 305, 200-208. http://dx.doi.org/10.1016/j.jhazmat.2015.11.041.

Descostes, M., Vitorge, P., Beaucaire, C., 2004. Pyrite dissolution in acidic media. Geochim. Cosmochim. Acta 68, 4559-4569. https://doi.org/10.1016/j.gca.2004.04.012.

Dev, S., Bhattacharya, J., 2014. Use of marine waste extract as a nitrogen source for biological sulfate reduction: development of a suitable alternative. Mine Water Environ. 33, 362-371. https://doi.org/10.1007/s10230-014-0283-7.

Dev, S., Patra, A.K., Mukherjee, A., Bhattacharya, J., 2015. Suitability of different growth substrates as source of nitrogen for sulfate reducing bacteria. Biodegradation 26, 415-430. https://doi.org/10.1007/s10230-014-0283-7.

Dev, S., Roy, S., Bhattacharya, J., 2016. Understanding the performance of sulfate reducing bacteria based packed bed reactor by growth kinetics study and microbial profiling. J. Environ. Manage. 177, 101-110. https://doi.org/10.1016/j.jenvman.2016.03.049.

Digesti, R.D., Weeth, H.J., 1976. A defensible maximum for inorganic sulfate in drinking water of cattle1 ,2. 42, 1498-1502. http://dx.doi.org/10.2527/jas1976.4261498x.

DiLoreto, Z.A., Weber, P.A., Olds, W., Pope, J., Trumm, D., Chaganti, S.R., Heath, D.D., Weisener, C.G., 2016. Novel cost effective full scale mussel shell bioreactors for metal removal and acid neutralization. J. Environ. Manage. 183, 601-612. http://dx.doi.org/10.1016/j.jenvman.2016.09.023.

Dou, W., Zhou, Z., Jiang, L.-M., Jiang, A., Huang, R., Tian, X., Zhang, W., Chen, D., 2017. Sulfate removal from wastewater using ettringite precipitation: Magnesium ion inhibition and process 
optimization.

J. Environ.

Manage.

196,

518-526.

http://dx.doi.org/10.1016/j.jenvman.2017.03.054.

Doughty, T., Littlejohn, P., 2015. Water treatment utilizing fluidized resin, https://www.appliedgeochemists.org/images/stories/IAGS_2015/Abstracts/27th\%20IAGS_Dou ghty\%20and\%20Littlejohn_SulfIX\%20Water\%20Treatment.pdf. Freeport-McMoRan Inc. 6200 .W. Duval Mine Rd. Green Valley, AZ USA 85622,

Doujaiji, B., Al-Tawfiq, J.A., 2010. Hydrogen sulfide exposure in an adult male. Ann. Saudi Med. 30, 76-80. https://dx.doi.org/10.4103/0256-4947.59379.

Du, Z., Li, H., Gu, T., 2007. A state of the art review on microbial fuel cells: A promising technology for wastewater treatment and bioenergy. Biotechnol. Adv. 25, 464-482. http://dx.doi.org/10.1016/j.biotechadv.2007.05.004.

Dutrizac, J.E., 1999. The effectiveness of jarosite species for precipitating sodium jarosite. JOM 51, 30-32. http://dx.doi.org/10.1007/s11837-999-0168-6.

Enning, D., Garrelfs, J., 2014. Corrosion of iron by sulfate-reducing bacteria: New views of an old problem. Appl. Environ. Microbiol. 80, 1226-1236. http://dx.doi.org/10.1128/AEM.02848-13.

Evangelou, V.P., 1995. Pyrite Oxidation and its Controlln: Anonymous, CRC Press, New York, pp. 275.

Feng, D., Aldrich, C., Tan, H., 2000. Treatment of acid mine water by use of heavy metal precipitation and ion exchange. Minerals Eng. 13, 623-642. http://dx.doi.org/10.1016/S0892-6875(00)000455 .

Flynn, D.J. (ed.), 2009. The Nalco Water Handbook, 3rd edition, McGraw Hill, New York, pp. 8.4-8.26.

$\begin{array}{lllll}\text { Fosso-Kankeu, } & \text { E., } & \text { Waanders, } & \text { F., } & \text { Steyn, }\end{array}$ Chitosan-graft-polyacrylamide adsorbent for sulfate removal from water, 7th International Conference on Latest Trends in Engineering \& Technology (ICLTET'2015) Nov. 26-27, Irene, Pretoria (South Africa), 99-102. http://dx.doi.org/10.15242/IIE.E111.

Frankel, G.S., 1998. Pitting corrosion of metals: A review of the critical factors. J. Electrochem. Soc. 145, 2186-2198. http://dx.doi.org/10.1149/1.1838615.

Franklin, C.A., Burnett, R.T., Paolini, R.J., Raizenne, M.E., 1985. Health risks from acid rain: a Canadian $\begin{array}{llll}\text { perspective. Health } \quad \text { Environ. } & \text { Perspect. }\end{array}$ https://www.ncbi.nlm.nih.gov/pmc/articles/PMC1568495/.

Fu, F., Wang, Q., 2011. Removal of heavy metal ions from wastewaters: A review. J Environ. Manage. 92, 407-418. https://doi.org/10.1016/j.jenvman.2010.11.011.

Gandy, C.J., Jarvis, A.P., 2012. The influence of engineering scale and environmental conditions on the performance of compost bioreactors for the remediation of zinc in mine water discharges. Mine Water Environ. 31, 82-91. http://dx.doi.org/10.1007/s10230-012-0177-5. 
Geethamani, C.K., Ramesh, S.T., Gandhimathi, R., Nidheesh, P.V., 2014. Alkali-treated fly ash for the removal of fluoride from aqueous solutions. Desal. Water Treat. 52, 3466-3476. http://dx.doi.org/10.1080/19443994.2013.800825.

Geldenhuys, A.J., Maree, J.P., De Beer, M., Hlabela, P., 2003. An integrated limestone/lime process for partial sulphate removal. J. S. Afr. Inst. Min. Metall. 103, 345-354. http://www.saimm.co.za/Journal/v103n06p345.pdf.

Ghalavand, Y., Hatamipour, M.S., Rahimi, A., 2015. A review on energy consumption of desalination processes. Des. Water Treat. 54, 1526-1541. https://doi.org/10.1080/19443994.2014.892837.

Giwa, A., Dufour, V., Al Marzooqi, F., Al Kaabi, M., Hasan, S.W., 2017. Brine management methods: Recent innovations and current status. Desalination 407, 1-23. https://doi.org/10.1016/j.desal.2016.12.008.

Glasser, F.P., Marchand, J., Samson, E., 2008. Durability of concrete - Degradation phenomena involving detrimental chemical reactions. Cem. Concr. Res. 38, 226-246. http://dx.org/10.1016/j.cemconres.2007.09.015.

Goh, P.S., Lau, W.J., Othman, M.H.D., Ismail, A.F., 2018. Membrane fouling in desalination and its mitigation strategies. Desalination 425, 130-155. https://doi.org/10.1016/j.desal.2017.10.018.

Goldstein, T.P., Aizenshtat, Z., 1994. Thermochemical sulfate reduction a review. J. Therm. Anal. 42, 241-290. http://dx.doi.org/10.1007/BF02547004.

Gomez, G.G., Sandler, R.S., Seal, E.J., 1995. High levels of inorganic sulfate cause diarrhea in neonatal piglets. J. Nutr. 125, 2325-2332.

Guimarães, D., Leão, V.A., 2014. Batch and fixed-bed assessment of sulphate removal by the weak base ion exchange resin Amberlyst A21. J. Hazard. Mater. 280, 209-215. https://doi.org/10.1016/j.jhazmat.2014.07.071.

Gupta, V.K., Kumar, R., Nayak, A., Saleh, T.A., Barakat, M.A., 2013. Adsorptive removal of dyes from aqueous solution onto carbon nanotubes: A review. Adv. Colloid Interface Sci. 193-194, 24-34. https://doi.org/10.1016/j.cis.2013.03.003

Gusek, J., Schueck, J., 2004. Bench and pilot scale test results: Passive treatment of acid mine drainage (AMD) at the Fran coal mine. PA, Tailings and Mine Waste'04: Proceedings of the Eleventh Tailings and Mine Waste Conference, Vail, Colorado, USA.

Gusek, J., 2004. Scaling Up Design Challenges for Large Scale Sulfate Reducing Bioreactors. Proceedings of the 2004 National Meeting of the American Society of Mining and Reclamation and the 25th WV surface Mine Drainage Task Force, Morgantown, WV.

Gustafsson, J.P., Akram, M., Tiberg, C., 2015. Predicting sulphate adsorption/desorption in forest soils: Evaluation of an extended Freundlich equation. Chemosphere 119, 83-89. https://doi.org/10.1016/j.chemosphere.2014.05.067. 
Haghsheno, R., Mohebbi, A., Hashemipour, H., Sarrafi, A., 2009. Study of kinetic and fixed bed operation of removal of sulfate anions from an industrial wastewater by an anion exchange resin. J. Haz. Mat. 166, 961-966. https://doi.org/10.1016/j.jhazmat.2008.12.009.

Hansen, T., 1994. Metabolism of sulfate-reducing prokaryotesIn: Anonymous, Antonie Van Leeuwenhoek. 66, pp. 165-185.

Hasan, M., Rotich, N., John, M., Louhi-Kultanen, M., 2017. Salt recovery from wastewater by aircooled eutectic freeze crystallization. Chem. Eng. J. 326, 192-200. http://dx.doi.org/10.1016/j.cej.2017.05.136.

Heikkinen, P.M., Räisänen, M.L., Johnson, R.H., 2009. Geochemical characterisation of seepage and drainage water quality from two sulphide mine tailings impoundments: Acid mine drainage versus neutral mine drainage. Mine Water Environ. 28, 30-49. http://dx.doi.org/10.1007/s10230-008-0056-2.

Hitchcock, D.R., 1975. Biogenic contributions to atmospheric sulfate levels. 292-310.

Hlabela, P., Maree, J., Bruinsma, D., 2007. Barium carbonate process for sulphate and metal removal from mine water. Mine Wat. Environ. 26, 14-22. https://doi.org/10.1007/s10230-007-0145-7.

Hong, S., Cannon, F.S., Hou, P., Byrne, T., Nieto-Delgado, C., 2014. Sulfate removal from acid mine drainage using polypyrrole-grafted granular activated carbon. Carbon 73, 51-60. http://dx.doi.org/10.1016/j.carbon.2014.02.036.

Hong, S., Cannon, F.S., Hou, P., Byrne, T., Nieto-Delgado, C., 2017. Adsorptive removal of sulfate from acid mine drainage by polypyrrole modified activated carbons: Effects of polypyrrole deposition protocols and activated carbon source. Chemosphere 184, 429-437. http://dx.doi.org/10.1016/j.chemosphere.2017.06.

Hou, P., Byrne, T., Cannon, F.S., Chaplin, B.P., Hong, S., Nieto-Delgado, C., 2014. Electrochemical regeneration of polypyrrole-tailored activated carbons that have removed sulfate. Carbon 79, 46-57. http://dx.doi.org/10.1016/i.carbon.2014.07.033

Hubert, E., Wolkersdorfer, C., 2015. Establishing a conversion factor between electrical conductivity and total dissolved solids in South African mine waters. Water SA 41, 490-500. http://dx.doi.org/10.4314/WSA.V41/4.08.

Hull, E.J., Zodrow, K.R., 2017. Acid Rock Drainage Treatment Using Membrane Distillation: Impacts of Chemical-Free Pretreatment on Scale Formation, Pore Wetting, and Product Water Quality. Environ. Sci. Technol. 51, 11928-11934. http://dx.doi.org/10.1021/acs.est.7b02957.

lakovleva, E., Mäkilä, E., Salonen, J., Sitarz, M., Sillanpää, M., 2015. Industrial products and wastes as adsorbents for sulphate and chloride removal from synthetic alkaline solution and mine process water. Chem. Eng. J. 259, 364-371. https://doi.org/10.1016/j.cej.2014.07.091.

INAP, 2003. Treatment of sulphate in mine effluents, International network for acid prevention. Available 
from http://www.inap.com.au/public_downloads/Research_Projects/Treatment_of_Sulphate_ in_Mine_Effluents_-_Lorax_Report.pdf (accessed in December 2015).

Ishiguro, M., Makino, T., Hattori, Y., 2006. Sulfate adsorption and surface precipitation on a volcanic ash soil (allophanic andisol). J. Colloid Interface Sci. 300, 504-510. https://doi.org/10.1016/j.jcis.2006.04.032.

Isosaari, P., Sillanpää, M., 2017. Use of sulfate-reducing and bioelectrochemical reactors for metal recovery from mine water. Sep. Purif. Rev. 46, 1-20. http://dx.doi.org/10.1080/15422119.2016.1156548.

Jarvie-Eggart, M.E., 2015. Responsible mining: Case studies in managing social \& Environmental Risks in the Developed World.

Jeen, S.-W., Bain, J.G., Blowes, D.W., 2014. Evaluation of mixtures of peat, zero-valent iron and alkalinity amendments for treatment of acid rock drainage. Appl. Geochem. 43, 66-79. http://dx.doi.org/10.1016/j.apgeochem.2014.02.004.

Jeen, S.-W., Mattson, B., 2016. Evaluation of layered and mixed passive treatment systems for acid $\begin{array}{llll}\text { mine } & \text { drainage. } & \text { 2835-2851. }\end{array}$ http://dx.doi.org/10.1080/09593330.2016.1167249.

Jiang, S., Li, Y., Ladewig, B.P., 2017. A review of reverse osmosis membrane fouling and control strategies. Sci. Tot. Env. 595, 567-583. https://doi.org/10.1016/j.scitotenv.2017.03.235.

Johnson, D., Hallberg, K., 2005. Acid mine drainage remediation options: a review. Sci. Total Environ. 338, 3-14. http://dx.doi.org/10.1016/j.scitotenv.2004.09.002.

Juholin, P., Kääriäinen, M., Riihimäki, M., Sliz, R., Aguirre, J.L., Pirilä, M., Fabritius, T., Cameron, D., Keiski, R.L., 2018. Comparison of ALD coated nanofiltration membranes to unmodified commercial membranes in mine wastewater treatment. Sep. Purif. Technol. 192, 69-77. https://doi.org/10.1016/j.seppur.2017.09.005.

Jung, S.P., Cheong, Y., Yim, G., Ji, S., Kang, H., 2015. Erratum to: Performance and bacterial communities of successive alkalinity-producing systems (SAPSs) in passive treatment processes treating mine drainages differing in acidity and metal levels. Environ. Sci. Pollut. Res. 22, 47884788. http://dx.doi.org/10.1007/s11356-014-3949-6.

Katal, R., Vafaie Sefti, M., Jafari, M., Saeedi Dehaghani, A.H., Sharifian, S., Ghayyem, M.A., 2012. Study effect of different parameters on the sulphate sorption onto nano alumina. J. Ind. Eng. Chem. 18, 230-236. https://doi.org/10.1016/j.jiec.2011.11.012.

Kefeni, K.K., Msagati, T.M., Maree, J.P., Mamba, B.B., 2015. Metals and sulphate removal from acid mine drainage in two steps via ferrite sludge and barium sulphate formation. Min. Eng. 81, 7987. https://doi.org/10.1016/j.mineng.2015.07.016. 
Kefeni, K.K., Msagati, T.A.M., Mamba B.B., 2017. Acid mine drainage: Prevention, treatment options, and resource recovery: A review. J. Clean. Prod. 151, 475-493. https://doi.org/10.1016/i.jclepro.2017.03.082

Khan, S.J., Murchland, D., Rhodes, M., Waite, T.D., 2009. Management of concentrated waste streams from high-pressure membrane water treatment systems. Environ. Sci. Technol. 39, 367415. https://doi.org/10.1080/10643380701635904.

Kim, D.H., 2011. A review of desalting process techniques and economic analysis of the recovery of salts from retentates. Desalination 270, 1-8. http://dx.doi.org/10.1016/i.desal.2010.12.041.

Klein, R., Tischler, J.S., Mühling, M., Schlömann, M., 2014. Bioremediation of Mine Water: Schippers, A., Glombitza, F., Sand, W. (Eds.), Geobiotechnology I: Metal-Related Issues, Springer Berlin Heidelberg, Berlin, Heidelberg, pp. 109-172.

Koshy, N., Singh, D.N., 2016. Fly ash zeolites for water treatment applications. J. Environ. Chem. Eng. 4, 1460-1472. https://doi.org/10.1016/j.jece.2016.02.002.

Koumaiti, S., Riahi, K., Ounaies, F., Ben Thayer, B., 2011. Kinetic modelling of liquid-Phase adsorption of sulfate onto raw date palm seeds. J. Env. Sci. Eng. 5, 1570-1580.

Kousi, P., Remoundaki, A., Hatzikioseyian, A., Tsezos, M., 2015. Sulphate-reducing bioreactors: current practices and perspectives. International water Association (IWA).

Kyllönen, H., Grönroos, A., Järvelä, E., Heikkinen, J., Tang, C., 2017. Experimental aspects of scaling control in membrane filtration of mine water. Mine Water Environ. 36, 193-198. https://doi.org/10.1007/s10230-016-0415-3.

Landaburu-Aguirre, J., García-Pacheco, R., Molina, S., Rodríguez-Sáez, L., Rabadán, J., García-Calvo, E., 2016. Fouling prevention, preparing for re-use and membrane recycling. Towards circular economy in RO desalination. Desalination 393, 16-30. https://doi.org/10.1016/j.desal.2016.04.002.

Lee, D.-J., Lee, C.-Y., Chang, J.-S., 2012. Treatment and electricity harvesting from sulfate/sulfidecontaining wastewaters using microbial fuel cell with enriched sulfate-reducing mixed culture. J. Hazard. Mater. 243, 67-72. http://dx.doi.org/10.1016/j.jhazmat.2012.09.071.

Lee, D.-J., Liu, X., Weng, H.-L., 2014. Sulfate and organic carbon removal by microbial fuel cell with sulfate-reducing bacteria and sulfide-oxidising bacteria anodic biofilm. Bioresour. Technol. 156, 14-19. http://dx.doi.org/10.1016/j.biortech.2013.12.129.

Lefèvre, E., Pereyra, L.P., Hiibel, S.R., Perrault, E.M., De Long, S.K., Reardon, K.F., Pruden, A., 2013. Molecular assessment of the sensitivity of sulfate-reducing microbial communities remediating 
mine drainage to aerobic stress. Water Res. 47, 5316-5325. http://dx.doi.org/10.1016/j.watres.2013.06.014.

Lefticariu, L., Walters, E.R., Pugh, C.W., Bender, K.S., 2015. Sulfate reducing bioreactor dependence on organic substrates for remediation of coal-generated acid mine drainage: Field experiments. Appl. Geochem. 63, 70-82. http://dx.doi.org/10.1016/j.apgeochem.2015.08.002.

Lens, P., Vallero, M., Esposito, G., Zandvoort, M., 2002. Perspectives of sulfate reducing bioreactors in environmental biotechnology. Rev. Environ. Sci. Biotechnol. 1, 311-325. http://dx.doi.org/10.1023/A:1023207921156.

Li, Y., Wang, J., Yue, Z., Tao, W., Yang, H., Zhou, Y., Chen, T., 2017. Simultaneous Chemical Oxygen Demand Removal, Methane Production and Heavy Metal Precipitation in the Biological Treatment of Landfill Leachate using Acid Mine Drainage as Sulfate Resource, J. Biosci. Bioeng. 124, 71-75. https://doi.org/10.1016/j.jbiosc.2017.02.009.

Liamleam, W., Annachhatre, A.P., 2007. Electron donors for biological sulfate reduction. Biotechnol. Adv. 25, 452-463. https://doi.org/10.1016/j.biotechadv.2007.05.002.

Liang, H.C., 2014. Trends in mine water treatment. Mining Magazine, 83-85.

Logan, B.E., Hamelers, B., Rozendal, R., Schröder, U., Keller, J., Freguia, S., Aelterman, P., Verstraete, W., Rabaey, K., 2006. Microbial Fuel Cells: Methodology and Technology. Environ. Sci. Technol. 40, 5181-5192. http://dx.doi.org/10.1021/es0605016.

Lottermoser, B., 2010. Mine Wastes: Characterization, Treatment and Environmental Impacts.

Machel, H.G., 2001. Bacterial and thermochemical sulfate reduction in diagenetic settings - old and new insights. Sediment. Geol. 140, 143-175. https://doi.org/10.1016/S0037-0738(00)00176-7.

Mackie, A., Farmer, H., Walsh, M., 2010a. Mine Water Treatment with Cement Kiln Dust (CKD). 139139-142.

Mackie, A., Boilard, S., Walsh, M.E., Lake, C.B., 2010b. Physicochemical characterization of cement kiln dust for potential reuse in acidic wastewater treatment. J. Hazard. Mater. 173, 283-291. https://doi.org/10.1016/j.jhazmat.2009.08.081.

Mackie, A.L., Walsh, M.E., 2012. Bench-scale study of active mine water treatment using cement kiln dust (CKD) as a neutralization agent. Water Res. 46, 327-334. https://doi.org/10.1016/j.watres.2011.10.030.

Madzivire, G., Petrik, L.F., Gitari, W.M., Ojumu, T.V., Balfour, G., 2010. Application of coal fly ash to circumneutral mine waters for the removal of sulphates as gypsum and ettringite. Minerals Eng. 23, 252-257. https://doi.org/10.1016/j.mineng.2009.12.004.

Mamelkina, M.A., Cotillas, S., Lacasa, E., Sáez, C., Tuunila, R., Sillanpää, M., Häkkinen, A., Rodrigo, M.A., 2017. Removal of sulfate from mining waters by electrocoagulation. Sep. Purif. Technol. 182, 87-93. https://doi.org/10.1016/j.seppur.2017.03.044. 
Maree, J.P., de Beer, M., Strydom, W.F., Christie, A.D.M., Waanders, F.B., 2004a. Neutralizing coal mine effluent with limestone to decrease metals and sulphate concentrations. Mine Wat. Environ. 23, 81-86. http://dx.doi.org/10.1007/s10230-004-0043-1.

Maree, J.P, Hlabela P., Nengovhela, R., Geldenhuys, A.J., Mbhele, N., Nevhulaudzi, T., Waanders, F.B, 2004b. Treatment of mine water for sulphate and metal removal using barium sulphide. Mine Wat. Environ, 23, 195-203. https://doi.org/10.1007/s10230-004-0062-y

Martí-Calatayud, M.C., Buzzi, D.C., García-Gabaldón, M., Ortega, E., Bernardes, A.M., Tenório, J.A.S., Pérez-Herranz, V., 2014. Sulfuric avid recovery from acid mine drainage by means of electrodialysis. Desalination 343, 120-127. https://doi.org/10.1016/j.desal.2013.11.031

Masindi, V., Osman, M.S., Abu-Mahfouz, A.M., 2017. Integrated treatment of acid mine drainage using BOF slag, lime/soda ash and reverse osmosis (RO): Implication for the production of drinking water. Desalination 424, 45-52. https://doi.org/10.1016/j.desal.2017.10.002

Matlock, M.M., Howerton, B.S., Atwood, D.A., 2002. Chemical precipitation of heavy metals from acid mine drainage. Water Res. 36, 4757-4764. http://dx..org/10.1016/S0043-1354(02)00149-5.

McCool, B.C., Rahardianto, A., Faria, J.I., Cohen, Y., 2013. Evaluation of chemically-enhanced seeded precipitation of RO concentrate for high recovery desalting of high salinity brackish water. Desalination 317, 116-126. https://doi.org/10.1016/j.desal.2013.01.010.

Ministery of social affairs and health, 461/2000. Ministery of social affairs and health (2000), 461/2000 Sosiaali- ja terveysministeriön asetus talousveden laatuvaatimuksista ja valvontatutkimuksista (In Finnish).

Minnesota Pollution Control Agency, 2014. Minnesota Pollution Control Agency.

Mirjafari, P., Baldwin, S.A., 2016. Decline in performance of biochemical reactors for sulphate removal from mine-influenced water is accompanied by changes in organic matter characteristics and microbial population composition. Water 8, 124. http://dx.doi.org/10.3390/w8040124.

Monteiro, P.J.M., 2005. Scaling and saturation laws for the expansion of concrete exposed to sulfate attack. Proc. Natl. Acad. Sci. U. S. A. 103, 11467-11472. http://dx.doi.org/10.1073/pnas.0604964103.

Moret, A., Rubio, J., 2003. Sulphate and molybdate ions uptake by chitin-based shrimp shells. Minerals Eng. 16, 715-722. https://doi.org/10.1016/S0892-6875(03)00169-9.

Morillo, J., Usero, J., Rosado, D., El Bakouri, H., Riaza, A., Bernaola, F., 2014. Comparative study of brine management technologies for desalination plants. Desalination 336, 32-49. https://doi.org/10.1016/j.desal.2013.12.038.

Moses, C.O., Kirk Nordstrom, D., Herman, J.S., Mills, A.L., 1987. Aqueous pyrite oxidation by dissolved oxygen and by ferric iron. Geochim. Cosmochim. Acta 51, 1561-1571. https://doi.org/10.1016/0016-7037(87)90337-1. 
Mount, D.R., Gulley, D.D., Hockett, J.R., Garrison, T.D., Evans, J.M., 1997. Statistical models to predict the toxicity of major ions to Ceriodaphnia dubia, Daphnia magna and Pimephales promelas (fathead minnows). Environ. Toxicol. Chem. 16, 2009-2019. http://doi.org//10.1002/etc.5620161005.

Muhammad, S.N., Kusin, F.M., Md Zahar, M.S., Mohamat Yusuff, F., Halimoon, N., 2017. Passive bioremediation technology incorporating lignocellulosic spent mushroom compost and limestone for metal- and sulfate-rich acid mine drainage. Environ. Technol. 38, 2003-2012. http://dx.doi.org/10.1080/09593330.2016.1244568.

Mulder, M., 1998. Basic principles of membrane technology. Kluwer academic publisher, Netherlands.

Mulinari, D.R., da Silva, M.L.C.P., 2008. Adsorption of sulphate ions by modification of sugarcane $\begin{array}{llll}\text { bagasse cellulose. } & \text { Carbohydr. } & \text { Polym. 74, }\end{array}$ https://doi.org/10.1016/j.carbpol.2008.04.014.

Mullett, M., Fornarelli, R., Ralph, D., 2004. Nanofiltration of Mine Water: Impact of Feed pH and Membrane Charge on Resource Recovery and Water Discharge. Membranes 4, 163-180. http://dx.doi.org/10.3390/membranes4020163.

Mulopo, J., 2016. Direct elemental sulphur recovery from gold acid mine drainage streams. J. Environ. Chem. Eng. 4, 4670-4679. https://doi.org/10.1016/j.jece.2016.11.002

Murugananthan, M., Bhaskar Raju, G., Prabhakar, S., 2004. Removal of sulfide, sulfate, and sulfite ions by electro coagulation. J. Hazard. Mater. 109, 37-44. https://doi.org/10.1016/j.jhazmat.2003.12.009

Muyzer, G., Stams, A.J.M., 2008. The ecology and biotechnology of sulphate-reducing bacteria. Nat. Rev. Microbiol. 6, 441-454. http://dx.doi.org/10.1038/nrmicro1892.

Naidu, G., Zhong, X., Vigneswaran, S., 2018. Comparison of membrane distillation and freeze crystallizer as alternatives for reverse osmosis concentrate treatment. Desalination 427, 10-18. https://doi.org/10.1016/j.desal.2017.10.043.

Namasivayam, C., Sangeetha, D., 2008. Application of coconut coir pith for the removal of sulfate and other anions from water. Desalination 219, 1-13. https://doi.org/10.1016/j.desal.2007.03.008.

Namasivayam, C., Sureshkumar, M.V., 2007. Removal of sulfate from water and wastewater by surfactant-modified coir pith, an agricultural solid "waste" by adsorption methodology. J. Environ. Eng. Manag. 17, 129-135.

Nariyan, E., Sillanpää, M., Wolkersdorfera, C., 2017. Electrocoagulation treatment of mine water from the deepest working European metal mine - Performance, isotherm and kinetic studies. Sep. Purif. Technol. 177, 363-373.https://doi.org/10.1016/j.seppur.2016.12.042.

Neculita, C.M., Zagury, G.J., 2008. Biological Treatment of Highly Contaminated Acid Mine Drainage in Batch Reactors: Long-Term Treatment and Reactive Mixture Characterization. J. Hazard. Mater. 157, 358-366. https://doi.org/10.1016/j.jhazmat.2008.01.002. 
Neculita, C.M., Zagury, G., Bussière, B., 2007. Passive treatment of acid mine drainage in bioreactors using sulfate-reducing bacteria. J. Environ. Qual. 36, 1-16. https://doi.org/10.2134/jeq2006.0066.

Ňancucheo, I., Barrie Johnson, D., 2014. Removal of sulfate from extremely acidic mine waters using low $\mathrm{pH}$ sulfidogenic bioreactors. Hydrometallurgy 150, 222-226. https://doi.org/10.1016/j.hydromet.2014.04.025.

Nilsson, R., Jokinen S., 1997. Method for the treatment of water treatment sludge. Patent US5674402A.

Nleya, Y., Simate, G.S.,Ndlovu, S., 2016. Sustainability assessment of the recovery and utilization of acid from acid mine drainage. J. Clean. Prod. 113, 17-27. https://doi.org/10.1016/j.jclepro.2015.11.005

Ntuli, F., Falayi, T., Thwanane, U., 2016. Removal of sulfates from acid mine drainage using desilicated fly ash slag. Proceedings of the 8th International Conference on Waste Management and The Environment, 383-390.

Nurmi, P., Özkaya, B., Sasaki, K., Kaksonen, A.H., Riekkola-Vanhanen, M., Tuovinen, O.H., Puhakka, J.A, 2010. Biooxidation and precipitation for iron and sulfate removal from heap bioleaching effluent streams. Hydrometallurgy 101, 7-14. https://doi.org/10.1016/j.hydromet.2009.11.004

Oliveira, C.R., Rubio, J., 2007a. New basis for adsorption of ionic pollutants onto modified zeolites. Minerals Eng 20, 552-558. https://doi.org/10.1016/j.mineng.2006.11.002.

O'Sullivan, A.D., Murray, D.A., Otte, M.L., 2004. Removal of sulfate, zinc, and lead from alkaline mine wastewater using pilot-scale surface-flow wetlands at Tara Mines, Ireland. Mine Water Environ 23, 58-65. https://doi.org/10.1007/s10230-004-0040-4.

Parviainen, A., 2012. Evolution of sulfide oxidation and attenuation mechanisms controlling acid mine drainage in decommissioned low-sulfide tailings, Aalto University Publication Series. Doctoral Dissertations.

Patent: PCT/FI2016/050587, Removal of sulfur substances from an aqueous medium with a solid material, WO 2017037335 A1.

Paterson, D.W., Wahlstrom, R.C., Libal, G.W., Olson, O.E., 1979. Effects of sulfate in water on swine reproduction and young-pig performance. J. Anim. Sci. 49, 664-667.

Peng, X., Tang, T., Zhu, X., Jia, G., Ding, Y., Chen, Y., Yang, Y., Tang, W., 2017. Remediation of acid mine drainage using microbial fuel cell based on sludge anaerobic fermentation. Environ.

Pérez-González, A., Urtiaga, A.M., Ibáñez, R., Ortiz, I., 2012. State of the art and review on the treatment technologies of water reverse osmosis concentrates. Wat. Res. 46, 267-283. https://doi.org/10.1016/j.watres.2011.10.046. 
Postgate, J., 1984. The sulphate-reducing bacteria: University Press, Cambridge. http://dx.doi.org/10.1002/jobm.3620250311.

Priyantha, N., Perera, S., 2000. Removal of sulfate, phosphate and colored substances in wastewater effluents using feldspar. Water Res. Manage. 14, 417-433. https://doi.org/10.1023/A:1011171330097.

Rabaey, K., Rozendal, R.A., 2010. Microbial electrosynthesis - Revisiting the electrical route for microbial production. Nat. Rev. Microbiol. 8, 706-716. http://dx.doi.org/10.1038/nrmicro2422.

Rahnemaie, R., Hiemstra, T., van Riemsdijk, H.M., 2006. Inner- and outer-sphere complexation of ions at the goethite-solution interface. J. Col. Int. Sci. 297, 379-388 Journal of Colloid and Interface Science. https://doi.org/10.1016/j.jcis.2005.11.003.

Ramla, B., Sheridan, C., 2015. The potential utilisation of indigenous South African grasses for acid mine drainage remediation. Water SA 41, 247-252. http://dx.doi.org/10.4314/wsa.v41i2.10.

Randall, D.G., Nathoo, J., 2015. A succinct review of the treatment of Reverse Osmosis brines using Freeze Crystallization. J. Wat. Proc. Eng. 8, 186-194. https://doi.org/10.1016/j.jwpe.2015.10.005.

Randall, D.G., Nathoo, J., Lewis, A.E., 2011. A case study for treating a reverse osmosis brine using Eutectic Freeze Crystallization-Approaching a zero waste process. Desalination 266, 256-262. https://doi.org/10.1016/j.desal.2010.08.034.

Rao, S.M., Sridharan, A., 1984. Mechanism of sulfate adsorption by kaolinite. Clays and Clay Minerals. 32, 414-418.

Rayner-Canham, G. (ed), 1999. New York, W.H. Freeman and Company.

Reiffenstein, R.J., Hulbert, W.C., Roths, S., 1992. Toxicology of Hydrogen-Sulfide. Annu. Rev. Pharmacol. Toxicol. 32, 109-134. htteps://doi.org/10.1146/annurev.pa.32.040192.000545.

Richter, J., Wiessner, A., Zehnsdorf, A., Müller, J.A., Kuschk, P., 2016. Injection of hydrogen gas stimulates acid mine drainage treatment in laboratory-scale hydroponic root mats. Eng. Life Sci. 16, 769-776. http://dx.doi.org/10.1002/elsc.201600009.

Ríos, C.A., Williams, C.D., Roberts, C.L., 2008. Removal of heavy metals from acid mine drainage (AMD) using coal fly ash, natural clinker and synthetic zeolites. J, Hazard. Mater. 156, 23-35. https://doi.org/10.1016/j.jhazmat.2007.11.123

Robertson, A., Everett, D., Du Plessis, P., 1993. Sulfate removal by GYPCIX process following lime treatment. In: SUPERFUND XIV Conference, 30/11-2/12/93, Washington USA.

Rose, A., Bisko, D., Daniel, A., Bower, M., Heckman, S., 2004. An "autopsy" of the Failed Tangaskootack\# 1 Vertical Flow Pond. Clinton Co., Pennsylvania, Proceedings America Society of Mining and Reclamation, 1580-1594. 
Rose, A., Morrow, T., Dunn, M., Denholm, C., 2007. Mode of Gypsum Precipitation in Vertical Flow Ponds. Proceedings America Society of Mining and Reclamation, 678-691.DOI

Rose, P., 2013. Long-term sustainability in the management of acid mine drainage wastewaters Development of the Rhodes BioSURE Process. Water SA 39, 583-592. http://dx.doi.org/10.4314/wsa.v39i5.1.

Rosenbaum, M., Aulenta, F., Villano, M., Angenent, L.T., 2011. Cathodes as electron donors for microbial metabolism: Which extracellular electron transfer mechanisms are involved? Biores. Technol. 102, 324-333. https://doi.org/10.1016/j.biortech.2010.07.008.

Rui, D., Yuanfa, L., Xingguo, W., Jianhua, H., 2011. Adsorption of sulfate ions from aqueous solution by surfactant-modified palygorskite. J. Chem. Eng. Data 56, 3890-3896. http://dx.doi.org/10.1021/je200544n.

Runtti, H., Luukkonen, T., Niskanen, M., Tuomikoski, S., Kangas, T., Tynjälä, P., Tolonen, E.-T., Sarkkinen, M., Kemppainen, K., Rämö, J., Lassi, U., 2016a. Sulfate removal over barium-modified blast-furnace-slag geopolymer. J. Haz. Mater. 317, 373-384. https://doi.org/10.1016/j.jhazmat.2016.06.001.

Runtti, H., Tuomikoski, S., Kangas, T., Kuokkanen, T., Rämö, J., Lassi, U., 2016b. Sulfate removal from water by carbon residue from biomass gasification: Effect of chemical modification methods on $\begin{array}{llll}\text { sulfate removal BioResour 11, 3136-3152. } & \text { efficiency. }\end{array}$ https://doi.org/10.15376/biores.11.2.3136-3152.

Runtti, H., Tynjälä, P., Tuomikoski, S., Kangas, T., Hu, T., Rämö, J., Lassi, U., 2017. Utilisation of bariummodified analcime in sulfate removal: Isotherms, kinetics and thermodynamics studies. J. Water Process. Eng. 16, 319-328. https://doi.org/10.1016/j.jwpe.2016.11.004.

Sadeghalvad, B., Azadmehr, A., Hezarkhani, A., 2016. Assessment of iron ore mineral wastes for sulfate removal from groundwater wells: A case study. RSC Adv. 6, 11719-11734. http://dx.doi.org/10.1039/c5ra21843h.

Sahinkaya, E., Yurtsever, A., Toker, Y., Elcik, H., Cakmaci, M., Kaksonen, A.H., 2015. Biotreatment of As-containing simulated acid mine drainage using laboratory scale sulfate reducing upflow anaerobic sludge blanket reactor. Minerals Eng 75, 133-139. http://dx.doi.org/10.1016/j.mineng.2014.08.012.

Salman, M.S., 2009. Removal of sulfate from waste water by activated carbon. Al-Khwarizmi Eng. J. $5,72-76$.

Sandoval, M.A., Nava, J.L., Coreño, O.,Carreño, G., Arias, L.A., Méndez, D., 2017. Sulfate lons Removal from an Aqueous Solution Modeled on an Abandoned Mine by Electrocoagulation Process withRecirculation. Int. J. Electrochem. Sci. 12, 1318-1330. https://doi.org/10.20964/2017.02.08.

Sánchez-Andrea, I., Sanz, J.L., Bijmans, M.F.M., Stams, A.J.M., 2014. Sulfate reduction at low pH to remediate acid mine drainage. J. Hazard. Mater. 269, 98-109. https://doi.org/10.1016/j.jhazmat.2013.12.032. 
Sang, P., Wang, Y., Zhang, L., Chai, L., Wang, H., 2013. Effective adsorption of sulfate ions with poly(mphenylenediamine) in aqueous solution and its adsorption mechanism. Trans. Nonferrous Met. Soc. China 23, 243-252. https://doi.org/10.1016/S1003-6326(13)62452-8.

Santos, A.L., Johnson, D.B., 2017. The effects of temperature and $\mathrm{pH}$ on the kinetics of an acidophilic sulfidogenic bioreactor and indigenous microbial communities. Hydrometal. 168, 116-120. http://dx.doi.org/10.1016/j.hydromet.2016.07.018.

Sapsford, D.J., Tufvesson, S., 2017. Properties of recycled sludge formed from different aluminiferous reagents during the ettringite process. J. Water Process. Eng. 19, 305-311. http://dx.doi.org/10.1016/j.jwpe.2017.08.016

Schoeman, J., Steyn, A., 2001. Investigation into alternative water treatment technologies for the treatment of underground mine water discharged by Grootvlei Proprietary Mines Ltd into the Blesbokspruit in South Africa. Desalination 133, 13-30. https://doi.org/10.1016/S00119164(01)00079-0.

Sheoran, A.S., Sheoran, V., Choudhary, R.P., 2010. Bioremediation of acid-rock drainage by sulphatereducing prokaryotes: A review. Minerals Eng. 23, 1073-1100. http://dx.doi.org/10.1016/j.mineng.2010.07.001.

Shengfeng, M.A., Changqiu, W., Anhuai, L.U., Hongliao, H.E., 2007. Experimental study on treatment of high-concentrated sulfur wastewater by process of depositing natrojarosite and its environmental significance. Acta Geologica Sinica 81, 330-334. (https://doi.org/10.1111/j.17556724.2007.tb00956.x).

Shirazi, S., Lin, C., Chen, D., 2010. Inorganic fouling of pressure-driven membrane processes - A critical review. Desalination 250, 236-248. https://doi.org/10.1016/j.desal.2009.02.056.

Silva, A.M., Lima, R.M.F., Leão, V.A., 2012. Mine water treatment with limestone for sulfate removal. J. Hazard. Mater. 221-222, 45-55. https://doi.org/10.1016/j.jhazmat.2012.03.066.

Sincero, A.P., Sincero, G.A., 2003. Physical-Chemical Treatment of Water and Wastewater. IWA Publishing, London.

Skousen, J., Zipper, C.E., Rose, A., Ziemkiewicz, P.F., Nairn, R., McDonald, L.M., Kleinmann, R.L., 2017. Review of passive systems for acid mine drainage treatment. Mine Water Environ. 36. http://dx.doi.org/10.1007/s10230-016-0417-1.

Smit, J.P., 1999. The treatment of polluted mine water. IMWA Proceedings. Mine, water \& environment. IMWA Congress, 467-467-471. 
Sokolova, T.A., Alekseeva, S.A., 2008. Adsorption of sulfate ions by soils (A Review). Eurasian Soil Scie. $41,140-148$.

Soucek, D.J., Kennedy, A.J., 2005. Effects of hardness, chloride, and acclimation on the acute toxicity of sulfate to freshwater invertebrates. Environ. Toxicol. Chem. 24, 1204-1210. http://dx.doi.org/10.1897/04-142.1.

Stone, H.W., Forstner, J.L., 1957. The Reduction of sulfate to sulfide in acid solutions by divalent chromium. J. Am. Chem. Soc. 79, 1840-1843. http://dx.doi.org/10.1021/ja01565a020.

Su, W., Zhang, L., Tao, Y., Zhan, G., Li, D., Li, D., 2012. Sulfate reduction with electrons directly derived from electrodes in bioelectrochemical systems. Electrochem. Commun. 22, 37-40. https://doi.org/10.1016/j.elecom.2012.04.030

Subramani, A., Jacangelo, J.G., 2014. Treatment technologies for reverse osmosis concentrate volume minimization: A review. Sep. Purif. Technol. 122, 472-489. https://doi.org/10.1016/j.seppur.2013.12.004.

Sun, H., Shi, B., Yang, F., Wang, D., 2017. Effects of sulfate on heavy metal release from iron corrosion scales in drinking water distribution system. Water Res. 114, 69-77. https://doi.org/10.1016/j.watres.2017.02.021.

Sutzkover-Gutman, I., Hasson, D., 2010. Feed water pretreatment for desalination plants. Desalination 264, 289-296. https://doi.org/10.1016/j.desal.2010.07.014.

Tait, S., Clarke, W.P., Keller, J., Batstone, D.J., 2009. Removal of sulfate from high-strength $\begin{array}{llll}\text { wastewater by } \text { Crystallization. Wat. } & \text { 762-772. }\end{array}$ https://doi.org/10.1016/j.watres.2008.11.008.

Tang, H., Pu, W.-C., Cai, C.-F., Xu, J.-P., He, W.-J., 2016. Remediation of acid mine drainage based on a novel coupled membrane-free microbial fuel cell with permeable reactive barrier system. Pol. J. Environ. Stud. 25, 107-112. http://dx.doi.org/10.15244/pjoes/60891.

Teng, W., Liu, G., Luo, H., Zhang, R., Xiang, Y., 2016. Simultaneous sulfate and zinc removal from acid wastewater using an acidophilic and autotrophic biocathode. J. Hazard. Mater. 304, 159-165. http://dx.doi.org/ 10.1016/j.jhazmat.2015.10.050.

Tolonen, E.-M., Hu, T., Rämö, J., Lassi, U., 2016a. The removal of sulphate from mine water by precipitation as ettringite and the utilisation of the precipitate as a sorbent for arsenate removal. J. Environ. Manage. 181, 856-862. https://doi.org/10.1016/j.jenvman.2016.06.053.

Tolonen, E., Luukkonen, T., Runtti, H., Rämö, J., Lassi, U., 2016b. Sorption of arsenate on ettringite formed in sulphate removal from mine drainage water, In: Proceedings IMWA 2016: Mining Meets Water - Conflicts and Solutions, TU Bergakademie, Freiberg, pp. 867-873. http://www.imwa.info/imwaconferencesandcongresses/proceedings/298-proceedings2016.html. 
Tolonen, E., Rämö, J., Lassi, U., 2015. The effect of magnesium on partial sulphate removal from mine water as gypsum. J. Environ. Manage. 159, 143-146. https://doi.org/10.1016/j.jenvman.2015.05.009.

Tolonen, E., Sarpola, A., Hu, T., Rämö, J., Lassi, U., 2014. Acid mine drainage treatment using byproducts from quicklime manufacturing as neutralization chemicals. Chemosphere 117, 419-424. https://doi.org/10.1016/j.chemosphere.2014.07.090.

Tsukamoto, T.K., Killion, H.A., Miller, G.C., 2004. Column experiments for microbiological treatment of acid mine drainage: Low-temperature, low-pH and matrix investigations. Water Res. 38, 14051418. http://dx.doi.org/10.1016/j.watres.2003.12.012.

Tuttle, J.H., Dugan, P.R., Randles, C.I., 1969. Microbial sulfate reduction and its potential utility as an acid mine water pollution abatement procedure. Appl. Microbiol. 17, 297-302.

UNEP, 1990. GEMS/Water data summary 1985-1987.

URS Corporation, 2003. Passive and semi-active treatment of acid rock drainage from metal mines State of the practice.

Valentene, T.M., Gomes, C.L., 2009. Occurrence, properties and pollution potential of environmental minerals in acid mine drainage. Sci. Tot. Environ. 407, 1135-1152. https://doi.org/10.1016/j.scitotenv.2008.09.050

Valverde, J., De Lucas, A., Carmona, M., Pérez, J., González, M., Rodríguez, J., 2006. Minimizing the environmental impact of the regeneration process of an ion exchange bed charged with transition metals. Sep. Purif. Technol. 49, 167173.https://doi.org/10.1016/j.seppur.2005.09.009.

Van Den Berg, M.F., Botes, M., Slabbert, E., Cloete, T.E., 2016. Evaluating sulphate removal and identifying the bacterial community present in acid mine drainage treated with synthetic domestic wastewater sludge. Water SA 42, 475-482. http://dx.doi.org/10.4314/wsa.v42i3.13.

Van der Meer, T., Nevatalo, L., Tanninen, J., 2014. Method of treating industrial water.

Vane, L. M., 2017. Water recovery from brines and salt-saturated solutions: operability and thermodynamic efficiency considerations for desalination technologies. J. Chem. Technol. Biotechnol. 92, 2506-2518. http://dx.doi.org/10.1002/jctb.5225.

Vasquez, Y., Escobar, M.C., Neculita, C.M., Arbeli, Z., Roldan, F., 2016. Biochemical passive reactors for treatment of acid mine drainage: effect of hydraulic retention time on changes in efficiency, composition of reactive mixture, and microbial activity. Chemosphere 153, 244-253. http://dx.doi.org/10.1016/j.chemosphere.2016.03.052.

Vet, R., Artz, R.S., Carou, S., Shaw, M., Ro, C., Aas, W., Baker, A., Bowersox, V.C., Dentener, F., GalyLacaux, C., Hou, A., Pienaar, J.J., Gillett, R., Forti, M.C., Gromov, S., Hara, H., Khodzher, T., Mahowald, N.M., Nickovic, S., Rao, P.S.P., Reid, N.W., 2014. A global assessment of precipitation 
chemistry and deposition of sulfur, nitrogen, sea salt, base cations, organic acids, acidity and $\mathrm{pH}$, and phosphorus. Atmos. Environ. 93, 3-100. https://doi.org/10.1016/j.atmosenv.2013.10.060.

Visser, T.J.K., Modise, S.J., Krieg, H.M., Keizer, K., 2001. The removal of acid sulphate pollution by nanofiltration. Desalination 140, 79-86. https://doi.org/10.1016/S0011-9164(01)00356-3.

Vujaković, A.D., Tomašević-Čanović, M.R., Daković, A.S., Dondur, V.T., 2000. The adsorption of sulphate, hydrogenchromate and dihydrogenphosphate anions on surfactant-modified clinoptilolite. Appl. Clay. Sci. 17, 265-277. https://doi.org/10.1016/S0169-1317(00)00019-3.

Wadekar, S.S., Hayes, T., Lokare, O.R., Mittal, D., Vidic, R.D., 2017. Laboratory and pilot-scale nanofiltration treatment of abandoned mine drainage for the recovery of products suitable for industrial reuse. Ind. Eng. Chem. Res. 56, 7355-7364. https://doi.org/10.1021/acs.iecr.7b01329.

Wetzel, R.G., 2001. Limonology: Lake and River Ecosystems. In: Elsevier (ed) San Diego, CA, Elsevier: 310-323.

WHO. 2017. Guidelines for drinking-water quality, 4th edition, incorporating the 1st addendum. http://www.who.int/water_sanitation_health/publications/drinking-water-quality-guidelines4-including-1st-addendum/en/.

WHO/UNEP, 1989. Global Environment Monitoring System: Global freshwater quality.

Wu, C., Kuo, C., Lin, C., Lo, S., 2002. Modeling competitive adsorption of molybdate, sulfate, selenate, and selenite using a Freundlich-type multi-component isotherm. Chemosphere 47, 283-292. https://doi.org/10.1016/S0045-6535(01)00217-X.

Wu. S., Kuschk, P., Wiessner, A., Müller, J., Saad, R.A.B., Dong, R., 2013. Sulphur transformations in constructed wetlands for wastewater treatment: A review. Ecol Eng 52: 278-289. https://doi.org/10.1016/j.ecoleng.2012.11.003.

Yavuz, Ö, Altunkaynak, Y., Güzel, F., 2003. Removal of copper, nickel, cobalt and manganese from aqueous solution by kaolinite. Water Res. 37, 948-952. https://doi.org/10.1016/S00431354(02)00409-8.

Zhang, M., Wang, H., 2016. Preparation of immobilized sulfate reducing bacteria (SRB) granules for effective bioremediation of acid mine drainage and bacterial community analysis. Minerals Eng. 92, 63-71. https://doi.org/10.1016/j.mineng.2016.02.008.

Zhao, F., Rahunen, N., Varcoe, J.R., Chandra, A., Avignone-Rossa, C., Thumser, A.E., Slade, R.C.T., 2008. Activated carbon cloth as anode for sulfate removal in a microbial fuel cell. Environ. Sci. Technol. 42, 4971-4976. https://doi.org/10.1021/es8003766. 